\title{
Biostratigraphy and Systematic Palaeontology of Late Cretaceous Heterohelicidae Foraminifera from Kurdistan Region North- eastern Iraq
}

\author{
Rawand B.N. Jaff \\ Department of General Science \\ College of Education and Languages \\ Charmo University. Iraq
}

\author{
Fadhil A.A. Lawa \\ Department of Geology \\ Faculty of sciences \\ University of Sulaimani. Iraq
}

(Received 5/5/2020 , Accepted 27/6/2020)

\begin{abstract}
The biostratigraphical importance and systematic palaeontology of Early Turonian to Early Maastrichtian Heterohelicidae Planktic foraminifera from Kurdistan region, NE Iraq are described. Some 24 species from 11 genera are recorded. Species abundance and diversity increase from the Early Turonian to Early Maastrichtian, perhaps signifying cooler sea temperatures in the Arabian sector of the Tethys Ocean during the Early Maastrichtian. Despite the long biostratigraphical ranges of some species, the importance of the biserial and multiserial Planktic foraminifers in Late Cretaceous biostratigraphy is emphasized. From a biostratigraphic perspective, heterohelicids are important for the definition of the Campanian-Maastrichtian boundary in Kurdistan region, with Planoglobulina species being especially important in this respect, as they are in Iran, Turkey and North Africa.
\end{abstract}

Key words: Late Cretaceous, Heterohelicidae, Systematic palaeontology, Kurdistan region, Iraq.

$$
\begin{aligned}
& \text { الطباقية الحياتية ودراسة تصنيفية لفورامنيفيرا الهيتيروهليسيدا (الكريتاسي الاعلى) من } \\
& \text { اقليم كردستان، شمال شرقي العراق } \\
& \text { فاضل احمد امين لاوه } \\
& \text { قسم الجبيولوجيا } \\
& \text { كلبة العلوم } \\
& \text { جامعة السلبيانية_|قليم كردستان - العلوم اق }
\end{aligned}
$$

\section{الملخص}

تم وصف الاهمية الطباقية الحياتية وتصنيف الحفريات الطافية الهيتيوروهلسيدا (Heterohelicidae) العائدة لعمر التورنيان المبكر الى الماسترختيان المبكر من كردستان. تم تسجيل حوالي 24 نوعًا من 11 جنسئًا.

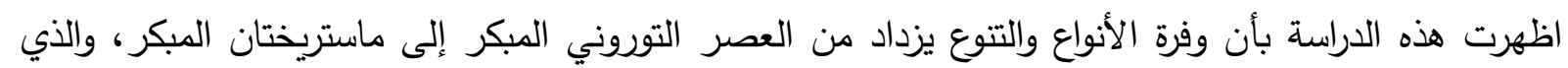

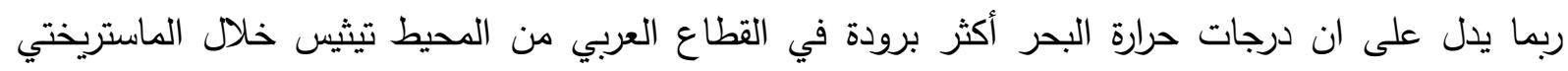
المبكر . على الرغم من النطاقات البيوستراتغرافية الطويلة لبعض الأنواع، فإن أهمية البقايا الثنائية التسلسل 


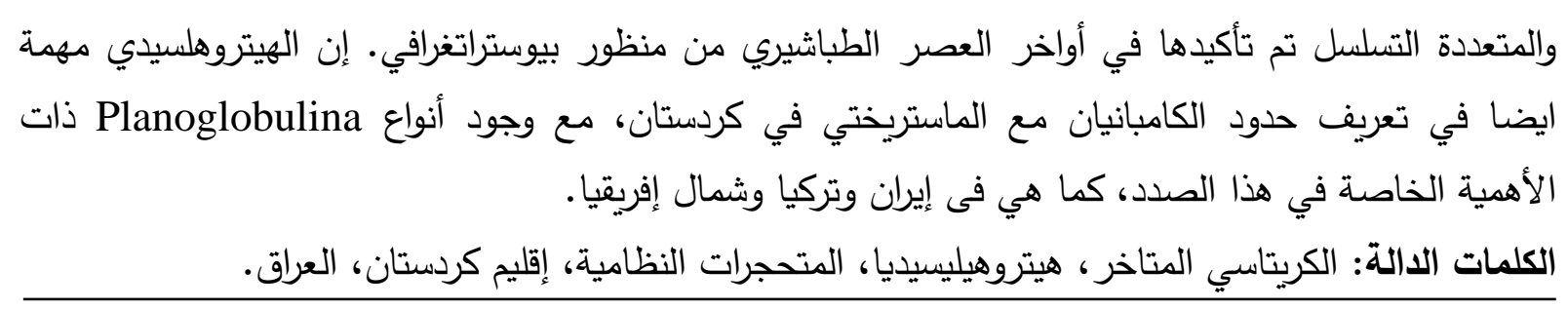

\section{INTRODUCTION}

The family Heterohelicidae Cushman 1927 forms one of the most common planktic foraminiferal groups in the Late Cretaceous (Early Turonian-Early Maastrichtian) Kometan and Shiranish formations in the Kurdistan region, NE Iraq (Fig. 1). Many Heterohelicid species show biostratigraphical potential, yet in Kurdistan relatively little attention has been paid to them, and their biostratigraphic and biogeographic significance are poorly known. However, more recently, AbdelKireem et al. (1996a), Robaszynski (1998), Li and Keller (1998a, 1998b, 1999), Li et al. (1999), Abramovich and Keller (2002, 2003), Abramovich et al. (2002, 2003, 2010, 2011), Huber et al. (2008), and Ogg and Hinnov (2012) enhanced Late Cretaceous planktic foraminiferal biozonation based on the Heterohelicidae. Two sections have been selected; the Azmer is located in the Zagros Imbricate Zone of Iraq, while the Dokan section is situated in the Zagros Foreland High Folds Zone (Lawa et al., 2013; Omar et al., 2015). The objectives of this study are: 1) to describe the species of the Heterohelicidae from the Kometan and Shiranish formations; and 2) to investigate in detail the biostratigraphical distribution of the heterohelicid planktic foraminifera in the Late Cretaceous (Early Turonian-Early Maastrichtian) of the Kurdistan region, NE Iraq.

\section{MATERIALS AND METHODS}

Two well exposed sections, at Dokan (latitude $35^{\circ} 56^{\prime} 15^{\prime \prime} \mathrm{N}$, longitude $44^{\circ} 57^{\prime}$ $21^{\prime \prime} \mathrm{E}$ ) and Azmer (latitude $35^{\circ} 37^{\prime} 30^{\prime \prime} \mathrm{N}$, longitude $45^{\circ} 31^{\prime} 45^{\prime \prime} \mathrm{E}$; see Fig. 1) were chosen for foraminiferal analysis. Some 411 samples have been collected from Kometan and Shiranish formations. For indurated rock samples, thin section analysis was used for heterohelicid identifications. For friable rock samples, a freeze-thaw method of processing was used (Jaff et al., 2014; 2015; Jaff and Lawa, 2019). Approximately 200-300 grams of each friable sample was repeatedly frozen and thawed in a supersaturated solution of sodium sulphate decahydrate until the rock disaggregated. The scattered sediments are then fully washed by a $63 \mu \mathrm{m}$ sieve and the residues separated by filtration and dried overnight with an oven temperature of $50^{\circ} \mathrm{C}$. Dried residues were sorted using sieve sizes from $500 \mu \mathrm{m}$ down to $63 \mu \mathrm{m}$. Heterohelicids were picked and studied from the residue in the $63-300 \mu \mathrm{m}$ size fractions. As a relative measure, heterohelicids are defined as rare where fewer than 5 specimens per sample are found and common where there are more than 5 specimens per sample. The heterohelicids were studied using a Hitachi S-3600N Scanning Electron Microscope (SEM) at the University of Leicester, UK. Materials for this study are stored in the collections of the British Geological Survey, Keyworth, and Nottingham, UK.

\section{LITHOSTRATIGRAPHY}

The Late Cretaceous (Early Turonian to Early Maastrichtian) strata of NE Iraq comprise two marine deposited formations: the pelagic limestone of the Kometan 
Formation (Early Turonian-Early Campanian) and the marly limestones and marlstones of the Shiranish Formation (Late Campanian-Early Maastrichtian). The Late Maastrichtian successions are characterized by the interfingering of Tanjero Formation with the reef dominated facies of Aqra Formation in both studied sections (Lawa et al., 2017; Lawa, 2018).

\section{Kometan Formation:}

The type section of the Kometan Formation was first described in an unpublished report by H.V. Dunnington (1953, fide van Bellen et al., 2005) from the village of Kometan near Endezeh in NE Iraq. At Endezeh, the formation comprises some $36 \mathrm{~m}$ of light grey, thinly bedded, globigerinal-oligosteginal limestone, locally silicified, with chert nodules, and glauconite especially at the base of the formation. According to a number of authors (e.g. Kaddouri, 1982; Al-Jassim et al., 1989; Al-Sheikhly et al., 1989; Abawi and Hammoudi, 1997; Hammoudi and Abawi, 2006; Haddad and Amin, 2007) the age of the Kometan Formation is Late Turonian at its base and extends to the Early Campanian at the top. However, more recently according to (Jaff et al., 2015) the base of the Kometan Formation extends to the Early Turonian based on the finding of the index planktic foraminifera Helvetoglobotruncana helvetica. The Kometan Formation is interpreted to be an outer shelf or basinal deposit (Jassim and Goff, 2006), becoming increasingly argillaceous to the west and southwest of Iraq. The base of the Kometan Formation is unconformable on the underlying Balambo and Qamchuqa formations in NE Iraq (which are Early Cenomanian; van Bellen et al., 2005; Buday, 1980; Jassim and Goff, 2006; Ameen and Gharib, 2014; Faris et al., 2019). The Kometan Formation has thicknesses of approximately $158 \mathrm{~m}$ and $96.5 \mathrm{~m}$ in the Dokan and Azmer areas respectively. In the Dokan area the formation is composed of well-bedded, light grey or white limestone with common chert nodules. The top of the Kometan Formation shows the local extinction of large ammonites. In the Azmer area the Kometan Formation is mainly composed of light grey, medium-bedded limestone, the lower part of the formation is associated with small, centimetre-scale ammonites, but towards the upper part of the formation there is a notable increase in the size of the Ammonites, which also become more common and lacks chert nodules.

\section{Shiranish Formation:}

The Shiranish Formation was first defined in an unpublished report by F.R.S. Henson (1940, fide van Bellen et al., 2005) from the 'High Folded Zone' of northern Iraq near the village of Shiranish Islam, NE of Zakho. The formation in its type section is about $228 \mathrm{~m}$ thick, and is informally subdivided into a 'lower unit' characterised by alternating marly limestone and calcareous marlstone that is rich in foraminifera, and an 'upper unit' that is dominated by blue marlstone (van Bellen et al., 2005; Aqrawi et al., 2010). According to several authors (Kennedy and Lunn 2000; Al-Banna 2010; Aqrawi et al., 2010; Jaff et al., 2014, 2015; Farouk et al., 2018; Jaff and Lawa, 2019) the age of the Shiranish Formation is Late Campanian to Maastrichtian, but it does not extend to the Late Maastrichtian (Kassab 1973; Jaff et al., 2014, 2015; Farouk et al., 2018; Jaff and Lawa, 2019). The formation in its type locality is interpreted to be an outer shelf to basinal deposit (Jassim and Goff, 2006) that unconformably overlies the Kometan Formation, and is succeeded conformably by marine clastic deposits of the Tanjero Formation in NE Iraq (Sharbazheri, 2008). The Shiranish Formation is well 
exposed in the localities studied and is about $260 \mathrm{~m}$ and $144 \mathrm{~m}$ thick in the Dokan and the Azmer areas respectively. In the Dokan area there is a glauconitic pebbly sandstone bed of around $0.5 \mathrm{~m}$ at the base of the 'lower unit' that may indicate a very slow rate of deposition or period of non-deposition (see Jaff et al., 2015; Farouk et al., 2018).

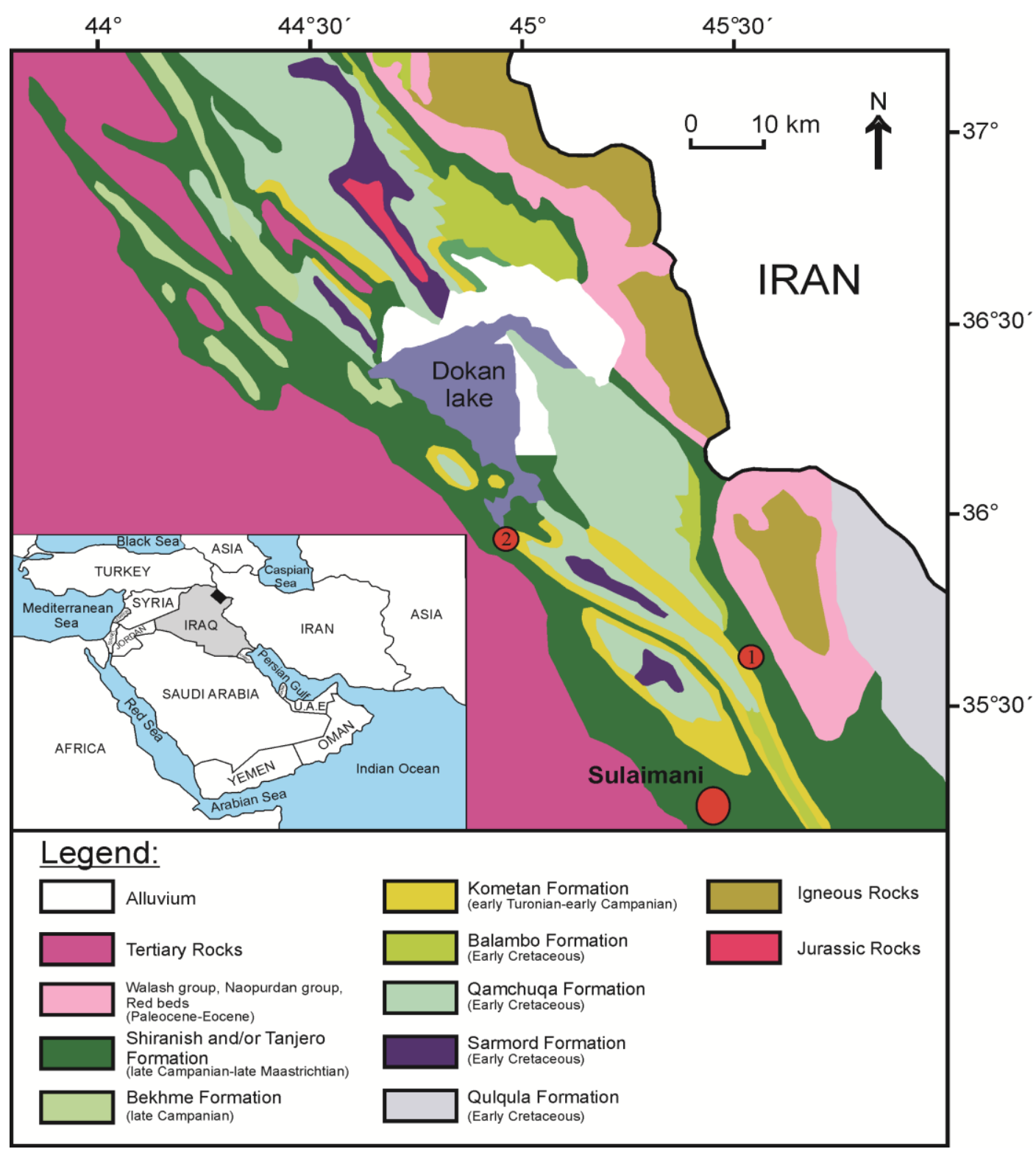

Fig. 1: Geological context for the Azmer (1) and Dokan (2) sections of the Kometan and Shiranish formations in the Kurdistan region, NE Iraq (after Sissakian, 2000).

\section{SYSTEMATIC PALAEONTOLOGY}

The terminology used to describe heterohelicids is shown in Figure (2). The stratigraphic ranges of the species as recorded by different authors, as well as in the present study, are shown in Figures (3-5). The taxonomic classification followed here is that of Pessagno (1967), Martin (1972), Smith and Pessagno (1973), Abdel-Kireem (1986), Nederbragt (1989, 1991), Abdel-Kireem et al. (1996b), Georgescu et al. (2008), Georgescu (1995, 2009), Haynes et al. (2015). 
Order Foraminiferida Eichwald, 1830

Suborder Globigerinina Delage and Hérouard, 1896

Superfamily Heterohelicacea Cushman, 1927

Family Heterohelicidae Cushman, 1927

Subfamily Heterohelicinae Cushman, 1927

Genus Praegublerina Georgescu, Saupe and Huber, 2008

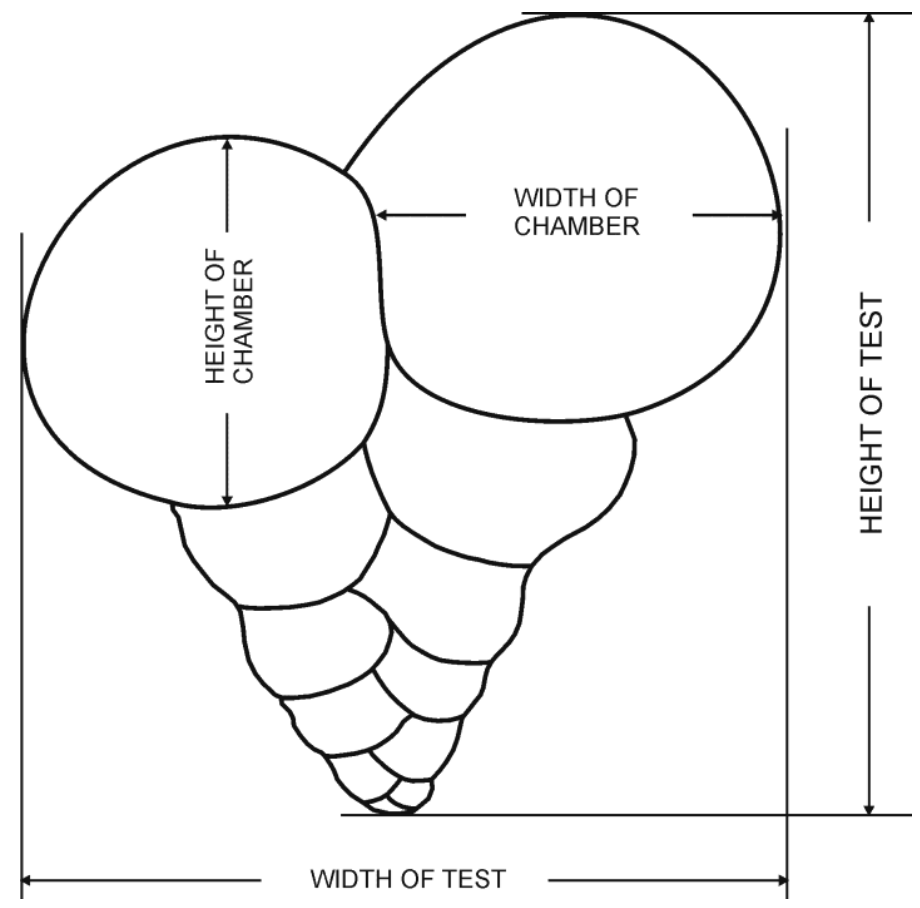

Fig. 2: Idealized biserial heterohelicid showing terminology used to measure and describe the morphology of the test after Abdel-Kireem et al. (1996b).

Genus Praegublerina Georgescu, Saupe and Huber, 2008

Praegublerina acuta (de Klasz, 1953), Plate 1, figs. 1-3

Gublerina acuta de Klasz, 1953, p. 246, 247, pl. 8, fig. 3; Weiss, 1983, p. 38, 39, pl. 1, figs. 1, 2; Nederbragt, 1989, p. 194, pl. 1, fig. 1; Nederbragt, 1991, p. 339, pl. 1, figs. 1, 2; Abramovich et al., 2003, p. 9, pl. II, fig. 9.

Praegublerina acuta (de Klasz). Georgescu et al., 2008, p. 408, 409, pl. 1, fig. A (3), pl. 4, figs. 1-4, pl. 6, figs 4-6.

-Material. 32 specimens from 20 samples.

-Dimensions. 12 specimens measured give the following dimensions: height of test 0.47-0.70 mm, width of test 0.33-0.63 mm.

-Remarks. In Kurdistan, Pg. acuta is differentiated from material of the type species of Gublerina, Gublerina cuvillieri Kikoine, 1948, by the more acute shape of the initial part of its test and by its overall less widely flaring shape: it can also be distinguished by having fewer chambers in the biserial part of the test, by having a narrow area of divergence between two rows of chambers, by the commencement of chamber divergence in the middle stage of the test, and by the presence of progressive elongate, sub-rectangular to reniform chambers over the divergence area in the multiserial portion of the test.

-Occurrence. (Early Maastrichtian; Fig. 3). 
Genus Gublerina Kikoine, 1948

Gublerina cuvillieri Kikoine, 1948, Plate 1, figs. 4-6

Gublerina cuvillieri Kikoine, 1948, p. 26, pl. 2, figs. 10a-c; de Klasz, 1953, p. 251, pl.

8, figs. 1, 2; Darmoian, 1975, p. 196, 197, pl. 2, fig. 16; Weiss, 1983, p. 39-41, pl.

1, fig. 4; Abdel-Kireem, 1986, p. 220, pl. 1, fig. 1, pl. 3, fig. 4; Nederbragt, 1989, p.

194, pl. 1, figs. 2, 3; Georgescu et al., 2008, pl. 1, figs. A (5, 6), pl. 5, figs. 6-11, pl.

6, figs. 7-9.

-Material. 23 specimens from 11 samples.

-Dimensions. 10 specimens measured give the following dimensions: height of test 0.50-0.77 mm, width of test $0.40-0.60 \mathrm{~mm}$.

-Remarks. In Kurdistan this species can be differentiated from Pg. acuta (de Klasz, 1953 ) by more widely flaring shape, by having more chambers in the biserial part of the test, by having a wider area of divergence between the two rows of chambers, and by the commencement of chamber divergence at an early stage of the test.

-Occurrence. (Early Maastrichtian; Fig. 3).

Genus Planoheterohelix Georgescu and Huber, 2009

Planoheterohelix globulosa (Ehrenberg, 1840), Plate 1, figs. 7-9, Plate 5, figs.1-4

Textularia globulosa Ehrenberg, 1840, p. 135, pl. 4, figs. 1B, 2B, 4B, 5B, 7B, 8B.

Gümbelina globulosa (Ehrenberg). White, 1929, p. 36, pl. 4, fig. 10; Cushman, 1938, p. 6, 7, pl. 1, figs. 28-33; Loeblich, 1951, p. 108, pl. 12, figs. 4, 5.

Heterohelix globulosa (Ehrenberg). Montanaro Gallitelli, 1957, p. 137, pl. 31, figs. 12-

15; Pessagno, 1967, p. 260, pl. 87, figs. 5-9, 11-13; Govindan, 1972, p. 167, pl. 1,

figs. 1, 2; Kassab, 1974, p. 80, 81, pl. 1, fig. 1; Frerichs et al., 1975, p. 300, pl. 1,

figs. 1, 2; Masters, 1980, p. 100, 101, pl. 1, figs. 6-8; Odébòdé, 1982, p. 238, 239,

pl. I, figs. 6, 7; Weiss, 1983, p. 44, pl. 1, figs. 8, 9; Abdel-Kireem, 1986, p. 222, pl.

1, figs 2-4, pl. 3, figs. 5, 6; Abdel-Kireem et al., 1996b, p. 244, 245, fig. $5(1,2)$;

Abramovich et al., 2003, p. 9, pl. II, figs. 1, 2; Abramovich et al., 2011, p. 147, pl.

2, figs. 1-6.

Planoheterohelix globulosa (Ehrenberg). Haynes et al., 2015, p. 55, 56, fig. 11 (1-14).

-Material. Over 10,000 specimens from all the samples of the Kometan and Shiranish formations.

-Dimensions. 50 specimens measured give the following dimensions: height of test $0.22-0.45 \mathrm{~mm}$, width of test $0.15-0.26 \mathrm{~mm}$, height of last chamber $0.10-0.15 \mathrm{~mm}$, width of last chamber $0.08-0.15 \mathrm{~mm}$.

-Remarks. The Kurdistani specimens of $\mathrm{Pl}$. globulosa have a range of surface ornamentation ranging from smooth to weakly developed discontinuous costae. $P l$. globulosa can be distinguished from Heterohelix striata by the inflated and globular last pair of chambers.

-Occurrence. (Early Turonian-Early Maastrichtian; Fig. 3).

Planoheterohelix moremani (Cushman, 1938), Plate 5, figs. 5-6

Gümbelina moremani Cushman, 1938, p. 10, pl. 2, figs. 1-3; Cushman, 1946, p. 103, pl. 44, figs. 15-17.

Heterohelix moremani (Cushman). Pessagno, 1967, p. 260, 261, pl. 48, figs. 10, 11, pl. 89, figs. 1, 2; Darmoian, 1975, p. 191, 192, pl. 1, fig. 3; Odébòdé, 1982, p. 239, 240, pl. I, fig. 12; Nederbragt, 1991, p. 344, pl. 2, figs. 6, 7, pl. 3, figs. 1, 2; 
Georgescu, 1995, p. 95, 96, pl. 1, figs. 3-5, 13; de Klasz et al., 1995, p. 363, pl. 2, fig. 4; Abdel-Kireem et al., 1996b, p. 245, fig. 5 (3).

Planoheterohelix moremani (Cushman). Georgescu and Huber, 2009, p. 244, 245, pl. 4, figs. 1-13; Haynes et al., 2015, p. 52, 53, fig. 9 (1-5).

-Material. 51 specimens from 17 samples.

-Dimensions. 10 specimens measured give the following dimensions: height of test $0.27-0.42 \mathrm{~mm}$, width of test $0.10-0.15 \mathrm{~mm}$, height of last chamber $0.07-0.09 \mathrm{~mm}$, width of last chamber $0.05-0.09 \mathrm{~mm}$.

-Remarks. In Kurdistan, $P l$. moremani can be separated from other biserial heterohelicids by having a smooth test surface, a larger number of chambers (reaching a maximum of 16; up to 18 chambers have been reported by Caron, 1985; Nederbragt, 1991; Abdel-Kireem et al., 1996b; Georgescu and Huber, 2009), and an elongate, slender shape.

-Occurrence. (Early Turonian-Coniacian; Fig. 3).

Planoheterohelix planata (Cushman, 1938), Plate 1, figs. 10-12, Plate 5, fig. 7 Gümbelina planata Cushman, 1938, p. 12, 13, pl. 2, figs. 13, 14; Cushman, 1946, p. 105, pl. 45, figs. $6,7$.

Heterohelix planata (Cushman). Pessagno, 1967, p. 261, 262, pl. 86, figs. 3, 4, pl. 89, figs. 6, 7; Kassab, 1974, p. 82, 83, pl. 1, fig. 3; Darmoian, 1975, p. 192, pl. 1, fig. 8; Frerichs et al., 1975, p. 300, 301, pl. 1, figs. 5, 6; Odébòdé, 1982, p. 240-242, pl. I, fig. 13, pl. II, fig. 1; Weiss, 1983, p. 44, 45, pl. 2, figs. 1-3; Abramovich et al., 2003, p. 9, pl. II, fig. 4; Georgescu et al., 2008, p. 402, pl. 1, fig. A (1), pl. 3, figs. 1-5; Abramovich et al., 2011, p. 147, pl. 2, figs. 15-17.

-Material. Over 500 specimens from Late Santonian to Early Maastrichtian samples of the Kometan and Shiranish formations.

-Dimensions. 50 specimens measured give the following dimensions: height of test $0.24-0.40 \mathrm{~mm}$, width of test $0.15-0.28 \mathrm{~mm}$, height of last chamber $0.08-0.13 \mathrm{~mm}$, width of last chamber $0.10-0.15 \mathrm{~mm}$.

-Remarks. The ovate and reniform adult chambers of this species are the characteristic feature for identification. Moreover, in some adult specimens an early stage of divergence between the two adult rows of chambers is seen. Cushman (1938) and Georgescu (1995) recorded Pl. planata with a keeled feature in the early portion of the test, but this feature is absent in Iraqi material (Kassab, 1974; Darmoian, 1975), Tunisia (Nederbragt, 1991), Egypt (Abdel-Kireem et al., 1996b), including that from Kurdistan. There is a superficial resemblance between the tests of Pl. planata and Laeviheterohelix pulchra (Brotzen, 1936); however, Pl. planata differs by lacking broad reniform chambers and flanges.

-Occurrence. (Late Santonian-Early Maastrichtian; Fig. 3).

Planoheterohelix reussi (Cushman, 1938), Plate 1, figs. 13-15, Plate 5, figs 8-9

Gümbelina reussi Cushman, 1938, p. 11, pl. 2, figs. 6-9; Cushman, 1946, p. 104, pl. 44, figs. 18, 19.

Heterohelix reussi (Cushman). Montanaro Gallitelli, 1957, p. 137, pl. 31, fig. 18; Pessagno, 1967, p. 263, pl. 85, figs. 1-9; pl. 86, figs. 1, 2; Darmoian, 1975, p. 194, pl. 1, figs. 16-20; Frerichs et al., 1975, p. 301, pl. 1, figs. 3, 4; Odébòdé, 1982, p. 242, pl. II, figs. 11, 12; Weiss, 1983, p. 47, 48, pl. 3, figs. 1, 2; Abdel-Kireem, 
1986, p. 222, 223, pl. 1, figs. 11, 12; Georgescu, 1995,pl. 2, figs. 1-3; AbdelKireem et al., 1996b, p. 247, fig. $5(8,9)$.

Planoheterohelix reussi (Cushman). Haynes et al., 2015, p. 57-59, fig. 18 (1-9).

-Material. Over 1000 specimens from Coniacian to Early Maastrichtian samples of the Kometan and Shiranish formations.

-Dimensions. 50 specimens measured give the following dimensions: height of test $0.15-0.30 \mathrm{~mm}$, width of test $0.10-0.20 \mathrm{~mm}$, height of last chamber $0.05-0.12 \mathrm{~mm}$, width of last chamber $0.05-0.10 \mathrm{~mm}$.

-Remarks. In Kurdistan, Pl. reussi can be distinguished from material of Pl. globulosa by having more compressed chambers, a triangular depression between the adult chambers, and a gradual increase of the last two adult chambers (rather than rapidly inflated chambers). Pl. reussi can be distinguished from material of $H$. striata by the absence of strong, continuous, closely spaced costae.

-Occurrence. (Coniacian-Early Maastrichtian; Fig. 3).

Genus Heterohelix Ehrenberg, 1843

Heterohelix semicostata (Cushman, 1938), Plate 2, figs. 1-2

Gümbelina semicostata Cushman, 1938, p. 16, pl. 3, fig. 6; Cushman, 1946, p. 107, pl. 46, figs. $1-5$.

Heterohelix semicostata (Cushman). Pessagno, 1967, p. 263, pl. 98, fig. 21; Darmoian, 1975, p. 194, pl. 2, fig. 3; Nederbragt, 1991, p. 348, pl. 4, figs. 2 , 4.

-Material. 11 specimens from 8 samples.

-Dimensions. 11 specimens measured give the following dimensions: height of test $0.30-0.36 \mathrm{~mm}$, width of test $0.21-0.25 \mathrm{~mm}$, height of last chamber $0.05-0.10 \mathrm{~mm}$, width of last chamber $0.12-0.15 \mathrm{~mm}$.

-Remarks. In Kurdistan, H. semicostata can be distinguished from material of Pseudoguembelina excolata by showing a more compressed test shape in edge view, by having a longer test, and by having costae concentrated along the periphery of the test.

-Occurrence. (Latest Campanian-Earliest Maastrichtian; Fig. 3).

Heterohelix striata (Ehrenberg, 1840), Plate 2, figs. 3-4

Textularia striata Ehrenberg, 1840, p. 135, pl. 4, figs. 1-3.

Gümbelina striata (Ehrenberg). Cushman, 1938, p. 8, 9, pl. 1, figs. 34-40; Cushman, 1946, p. 104, pl. 45, figs. 4, 5.

Pseudoguembelina striata (Ehrenberg). Brönnimann and Brown, 1953, p. 154, text fig. 6.

Heterohelix striata (Ehrenberg). Pessagno, 1967, p. 264, pl. 78, figs. 4, 5, pl. 88, figs. 3-7, pl. 98, fig. 16; Govindan, 1972, p. 168, pl. 1, figs. 13, 14; Smith and Pessagno, 1973, p. 19, 20, pl. 3, figs. 8-11, pl. 4, figs. 1-4; Darmoian, 1975, p. 194-196, pl. 2, figs. 4-7; Frerichs et al., 1975, p. 301, pl. 1, figs. 11, 12; Masters, 1980, p. 101, pl. 1, figs. 9-11; Weiss, 1983, p. 48, pl. 3, figs. 5, 6; Abramovich et al., 2011, p. 147, pl. 2, figs. 7-11.

-Material. Over 200 specimens from Late Campanian to Early Maastrichtian samples. -Dimensions. 50 specimens measured give the following dimensions: height of test $0.22-0.38 \mathrm{~mm}$, width of test $0.12-0.20 \mathrm{~mm}$, height of last chamber $0.10-0.12 \mathrm{~mm}$, width of last chamber $0.06-0.12 \mathrm{~mm}$. 
-Remarks. In Kurdistan, the species can be distinguished from material of $\mathrm{Pl}$. globulosa (Ehrenberg, 1840) in its well-developed, continuous, stronger costae, and less inflated adult chambers.

-Occurrence. (Late Campanian-Early Maastrichtian; Fig. 3).

Heterohelix ultimatumida (White, 1929), Plate 2, figs. 5-6

Gümbelina ultimatumida White, 1929, p. 39, pl. 4, fig. 13; Cushman, 1938, p. 13, 14, pl. 2, figs. 17, 18; Cushman, 1946, p. 107, pl. 46, figs. 6, 7.

Heterohelix ultimatumida (White). Pessagno, 1967, p. 264, 265; Govindan, 1972, p. 168, pl. 1, figs 3, 4; Darmoian, 1975, p. 196, pl. 2, figs. 10-13; Abdel-Kireem et al., 1996b, p. 248, fig. 5 (11); Abramovich et al., 2011, p. 147, pl. 2, fig. 14.

-Material. 86 specimens from Late Campanian to Early Maastrichtian samples.

-Dimensions. Height of test 0.33-0.50 mm, width of test $0.25-0.33 \mathrm{~mm}$, height of last chamber 0.12-0.26 mm, width of last chamber 0.18-0.23 mm.

-Remarks. The species is closely related to H. striata (Ehrenberg, 1840), but is distinguished by the presence of the enlarged penultimate and ultimate, and weaker costae. H. ultimatumida can be distinguished from material of Pl. globulosa (Ehrenberg, 1840) by having fewer chambers, and by the final chamber being more inflated than the previous chambers.

-Occurrence. (Late Campanian-Early Maastrichtian; Fig. 3).

Genus Braunella Georgescu, 2007

Braunella punctulata (Cushman, 1938), Plate 2, figs. 7-9, Plate 5, fig. 10

Gümbelina punctulata Cushman, 1938, p. 13, pl. 2, figs. 15, 16; Cushman, 1946, p. 108, pl. 46, figs. 13, 14.

Pseudoguembelina punctulata (Cushman). Brönnimann and Brown, 1953, text figs 7 , 8.

Heterohelix punctulata (Cushman). Pessagno, 1967, p. 262, 263, pl. 86, figs. 7-10;

Kassab, 1974, p. 84, 85, pl. 1, fig. 5; Nederbragt, 1989, p. 198, pl. 3, figs. 5-7;

Nederbragt, 1991, p. 346, pl. 3, fig. 6; Abdel-Kireem et al., 1996b, p. 246, fig. 5 (6,

7); Abramovich et al., 2003, p. 9, pl. II, fig. 5.

Braunella punctulata (Cushman). Georgescu, 2007, p. 158-160, pl. 1, figs. 1-5, pl. 3, figs. $1,3,4$.

-Material. 92 specimens from Late Campanian to Early Maastrichtian samples.

-Dimensions. 10 specimens measured give the following dimensions: height of test $0.45-0.53 \mathrm{~mm}$, width of test $0.30-0.37 \mathrm{~mm}$, height of last chamber $0.20-0.25 \mathrm{~mm}$, and width of last chamber $0.15-0.20 \mathrm{~mm}$.

-Remarks. The Kurdistani material of B. punctulata is often recognised by the short initial portion of the test forming a ' $\mathrm{V}$ ' shape and the rapidly increasing adult portion of the test with nearly uniform width in the last two or three pairs of chambers.

-Occurrence. (Late Campanian-Early Maastrichtian; Fig. 3).

Genus Paraspiroplecta Georgescu and Abramovich, 2008

Paraspiroplecta navarroensis (Loeblich, 1951), Plate 2, figs. 10-12

Heterohelix navarroensis Loeblich, 1951, p. 107, 108, pl. 12, figs. 1-3b; Montanaro Gallitelli, 1957, p. 137, pl. 31, figs. 5-11; Pessagno, 1967, p. 261, pl. 89, figs. 8, 9; Smith and Pessagno, 1973, p. 18, 19, pl. 3, figs. 4-7; Kassab, 1974, p. 81, 82, pl. 1, 
fig. 2; Weiss, 1983, p. 44, pl. 1, figs. 10, 11 Abramovich et al., 2011, p. 147, pl. 3, figs. 1-4.

Paraspiroplecta navarroensis (Loeblich). Georgescu and Abramovich, 2008, p. 109, 110, pl. 4, figs. 1-11.

-Material. Over 500 specimens from Early Maastrichtian samples.

-Dimensions. 50 specimens measured give the following dimensions: height of test $0.22-0.35 \mathrm{~mm}$, width of test $0.15-0.23 \mathrm{~mm}$, height of last chamber $0.12-0.13 \mathrm{~mm}$, width of last chamber $0.08-0.13 \mathrm{~mm}$.

-Remarks. In the Kurdistani material, the initial planispiral coil is distinctive and well developed. On the basis of this character, the species can be distinguished from all other biserial heterohelicids.

-Occurrence. (Early Maastrichtian; Fig. 3).

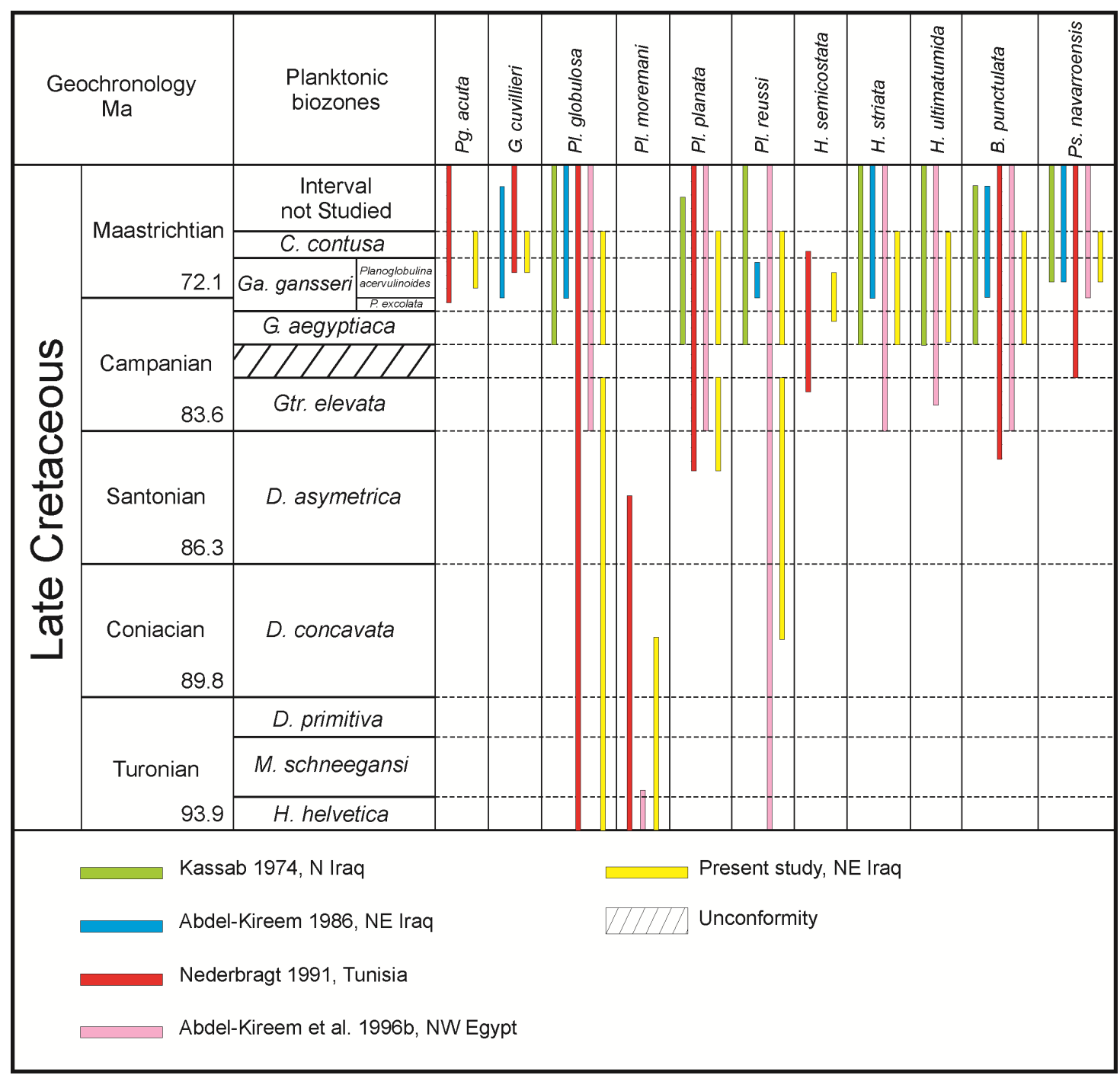

Fig. 3: Biostratigraphic ranges of Praegublerina (Pg.), Gublerina (G.), Planoheterohelix $(P l$.$) , Heterohelix (H.), Braunella (B.) and Paraspiroplecta (Ps.) species recorded in$ Kurdistan region, NE Iraq and their equivalent ranges in North Africa. Planktonic foraminiferal biozones after Jaff et al. (2015). Time scale adapted from Ogg and Hinnov (2012). Planktonic biozones abbreviations: $H .=$ Helvetoglobotruncana; $M .=$ Marginotruncana $;$ D. = Dicarinella $;$ Gtr. = Globotruncanita $;$ G. = Globotruncana $; G a .=$ Gansserina $;$ P. = Pseudoguembelina C. = Contusotruncana. 
Genus Laeviheterohelix Nederbragt, 1991

Laeviheterohelix dentata (Stenestad, 1968), Plate 2, figs. 13-15, Plate 5, figs. 11, 12 Heterohelix dentata Stenestad, 1968, p. 67, pl. 1, figs. 3-6, 8, 9, pl. 2, figs. 1-3; Nederbragt, 1989, p. 194, pl. 1, figs. 4-7. Laeviheterohelix dentata (Stenestad). Nederbragt, 1991, p. 350, pl. 5, figs. 1, 2. Laeviheterohelix dentata (Stenestad). Nederbragt, 1991, p. 350, pl. 5, figs. 1, 2. -Material. 54 specimens from 36 samples.

-Dimensions. 12 specimens measured give the following dimensions: height of test $0.28-0.45 \mathrm{~mm}$, width of test $0.15-0.30 \mathrm{~mm}$, height of last chamber $0.06-0.12 \mathrm{~mm}$, width of last chamber $0.10-0.20 \mathrm{~mm}$.

-Remarks. In Kurdistan, material of L. dentata can be distinguished by its subquadrate to reniform adult chambers and chambers overlapping in the adult portion of the test.

-Occurrence. (Latest Campanian-Early Maastrichtian; Fig. 4).

Laeviheterohelix glabrans (Cushman, 1938), Plate 3, figs. 1-3

Gümbelina glabrans Cushman, 1938, p. 15, pl. 3, figs. 1, 2; Cushman, 1946, p. 109, pl. 46, figs. $17,18$.

Heterohelix glabrans (Cushman). Pessagno, 1967, p. 259, pl. 88, figs. 1, 2, 10, 11;

Govindan, 1972, p. 169, pl. 1, figs. 11, 12; Smith and Pessagno, 1973, p. 17, 18, pl.

2, figs. 8-10, pl. 3, figs. 1-3; Darmoian, 1975, p. 191, pl. 1, fig. 7; Weiss, 1983, p.

43 , pl. 1, figs. 6,7 ;

Laeviheterohelix glabrans (Cushman). Nederbragt, 1991, p. 352, pl. 5, fig. 6; Abramovich et al., 2003, p. 9, pl. II, fig. 6; Abramovich et al., 2011, p. 147, pl. 3, figs. 10-12.

-Material. Over 100 specimens from 46 samples.

-Dimensions. 20 specimens measured give the following dimensions: height of test $0.28-0.35 \mathrm{~mm}$, width of test $0.18-0.24 \mathrm{~mm}$, height of last chamber $0.10-0.16 \mathrm{~mm}$, width of last chamber $0.10-0.15 \mathrm{~mm}$.

-Remarks. The species shows a close resemblance to L. dentata (Stenestad, 1968). The two species can be differentiated by the shape of the initial and penultimate chambers: those of L. glabrans are rounded to sub-rounded; while in L. dentata the chambers are sub-quadrate to reniform. L. glabrans can also be differentiated from L. pulchra (Brotzen, 1936) by the shape of its penultimate and ultimate chambers, which are almost as broad as high, rather than reniform.

-Occurrence. (Latest Campanian-Early Maastrichtian; Fig. 4).

Laeviheterohelix pulchra (Brotzen, 1936), Plate 3, figs.4-5, Plate 5, fig. 13

Gümbelina pulchra Brotzen, 1936, p. 121, pl. 9, fig. 3; Cushman, 1938, p. 12, pl. 2, fig. 12.

Heterohelix pulchra (Brotzen). Montanaro Gallitelli, 1957, p. 137, pl. 31, fig. 20; Pessagno, 1967, p. 262, pl. 87, fig. 4; Govindan, 1972, p. 168, pl. 1, figs. 9, 10; Kassab, 1974, p. 83, 84, pl. 1, fig. 4; Darmoian, 1975, p. 192, 193, pl. 1, figs. 9-15; Frerichs et al., 1975, p. 301, pl. 1, figs. 7, 8; Odébòdé, 1982, p. 242, pl. II, figs. 610; Weiss, 1983, p. 46, 47, pl. 2, figs. 9-13; Nederbragt, 1989, p. 198, pl. 3, figs. 3, 4; Georgescu, 1995, p. 96, pl. 1, figs. 6-8. 
Laeviheterohelix pulchra (Brotzen). Nederbragt, 1991, p. 352-354, pl. 5, fig. 7, pl. 6, fig. 1; Georgescu, 2009, p. 322, fig. 7 (1-5), fig. 8 (1-3); Abramovich et al., 2011, p. 147, pl. 3, fig. 13.

-Material. Over 200 specimens from Late Santonian to Late Campanian samples of the Kometan and Shiranish formations.

-Dimensions. 50 specimens measured give the following dimensions: height of test $0.26-0.46 \mathrm{~mm}$, width of test $0.18-0.30 \mathrm{~mm}$, height of last chamber $0.16-0.20 \mathrm{~mm}$, width of last chamber $0.10-0.12 \mathrm{~mm}$.

-Remarks. The species can be distinguished by its broad, reniform, final elongate chambers and smooth test. In Kurdistan, the important characteristic feature of $L$. pulchra is the presence of flanges in the last two or three rows of the adult chambers.

-Occurrence. (Latest Santonian-Latest Campanian; Fig. 4).

\section{Genus Planoglobulina Cushman, 1927}

Planoglobulina acervulinoides (Egger, 1899), Plate 3, figs. 6-8, Plate 5, figs. 14-15 Gümbelina acervulinoides Egger, 1899, p. 36, pl. 14, fig. 20 (not figs. 14-18, 21-22). Planoglobulina acervulinoides (Egger). White, 1929, p. 33, pl. 4, fig. 6; Cushman, 1938, p. 23, pl. 4, figs. 5-8; Cushman, 1946, p. 111, pl. 47, figs. 12-15; Pessagno, 1967, p. 271, pl. 87, fig. 14; Martin, 1972, p. 81, pl. 3, figs. 3-6; Kassab, 1978, p. 73-75, pl. 1, figs. 1, 2; Weiss, 1983, p. 50, pl. 4, figs. 5-7; Abdel-Kireem, 1986, p. 223, pl. 2, fig. 1; Nederbragt, 1989, p. 200, pl. 4, figs. 4-6, pl. 5, figs. 1, 2; Nederbragt, 1991, p. 356, pl. 6, figs. 5, 6, pl. 7, fig. 1; Georgescu, 1995, p. 97, pl. 2, figs. 4-6, 9; Abramovich et al., 2003, p. 13, pl. IV, fig. 11.

-Material. 85 specimens from 41 samples.

-Dimensions. 15 specimens measured give the following dimensions: height of test 0.50-0.56 mm, width of test 0.50-0.68 mm.

-Remarks. In Kurdistan it can be distinguished from material of P. brazoensis Martin, 1972 by having a less inflated test and more numerous chambers in the multiserial portion of the test.

-Occurrence. (Early Maastrichtian; Fig. 4).

Planoglobulina brazoensis Martin, 1972, Plate 3, figs. 9-11, Plate 5, fig. 16 Planoglobulina brazoensis Martin, 1972, p. 82, 83, pl. 3, fig. 7, pl. 4, figs. 1, 2; Smith and Pessagno, 1973, p. 20, pl. 4, figs. 5-10, pl. 5, figs. 1, 2; Weiss, 1983, p. 51, pl. 4, figs. 1-4; Abdel-Kireem, 1986, p. 223, pl. 2, fig. 4; Abramovich et al., 2003, p. 13, pl. IV, fig. 10; Abramovich et al., 2011, p. 148, pl. 4, figs. 11, 12.

-Material. 22 specimens from 17 samples.

-Dimensions. 10 specimens measured give the following dimensions: height of test 0.53-0.58 mm, width of test $0.40-0.47 \mathrm{~mm}$.

-Remarks. The Kurdistani specimens can be distinguished from other species of Planoglobulina by its globular chambers, which are greatly inflated in the later stage of the biserial portion, and the early stage of the multiserial portion of the test. The species is also separated from material of $P$. acervulinoides (Egger, 1899) by having a more inflated test and smaller number of chambers in the multiserial portion of the test.

-Occurrence. (Early Maastrichtian; Fig. 4). 
Planoglobulina carseyae (Plummer, 1931), Plate 3, fig. 12, Plate 4, figs. 1-2 Ventilabrella carseyae Plummer, 1931, p. 178, 179, pl. 9, figs. 7-9, not fig. 10; Cushman, 1938, p. 26, 27, pl. 4, figs. 20-24; Cushman, 1946, p. 112, pl. 48, figs. 15; Loeblich, 1951, p. 109, pl. 12, figs. 6-8.

Planoglobulina carseyae (Plummer). Montanaro Gallitelli, 1957, p. 141, pl. 32, fig. 13; Pessagno, 1967, p. 271, 272, pl. 87, figs. 10, 15, 16; Martin, 1972, p. 83, pl. 4, figs. 4-7; Govindan, 1972, p. 171, 172, pl. 1, fig. 17; Smith and Pessagno, 1973, p. 21, 22, pl. 5, figs. 3-12; Weiss, 1983, p. 51, 52, pl. 5, figs. 1-4; Abdel-Kireem, 1986, p. 223, pl. 2, figs. 2, 3, pl. 3, fig. 9; Nederbragt, 1989, p. 200, pl. 5, figs. 3-5; Nederbragt, 1991, p. 356, pl. 7, figs. 2, 3; Abramovich et al., 2003, p. 13, pl. IV, fig. 9; Abramovich et al., 2011, p. 148, pl. 4, figs. 13-16.

-Material. 33 specimens from 31 samples.

-Dimensions. 10 specimens measured give the following dimensions: height of test $0.40-0.50 \mathrm{~mm}$, width of test $0.30-0.35 \mathrm{~mm}$.

-Remarks. In Kurdistan, P. carseyae can be distinguished from other Planoglobulina species by its early biserial chambers occupying more than half of the test, followed by one or two sets of the multiserial chambers in the later portion of the test.

-Occurrence. (Early Maastrichtian; Fig. 4).

Planoglobulina riograndensis (Martin, 1972), Plate 4, fig. 3

Ventilabrella riograndensis Martin, 1972, p. 88, 89, pl. 2, figs. 1-4.

Planoglobulina riograndensis (Martin). Weiss, 1983, p. 54, pl. 5, figs. 5, 6;

Nederbragt, 1989, p. 200, pl. 6, figs. 1, 2; Nederbragt, 1991, p. 358, pl. 7, figs. 6, 7.

-Material. 1 specimen.

-Dimensions. height of test $0.56 \mathrm{~mm}$, width of test $0.55 \mathrm{~mm}$.

-Remarks. The Kurdistani specimen closely resembles to $P$. riograndensis recorded by Nederbragt (1991, p. 357, pl. 7, fig. 7) in Tunisia. Martin (1972) mentioned that $P$. riograndensis resembles Ventilabrella eggeri Cushman, 1928 in test shape, but the two differ in ornamentation. The Iraqi $P$. riograndensis also differs from $V$. eggeri by the shape of the penultimate and ultimate chambers.

-Occurrence. (Early Maastrichtian; Fig. 4). 


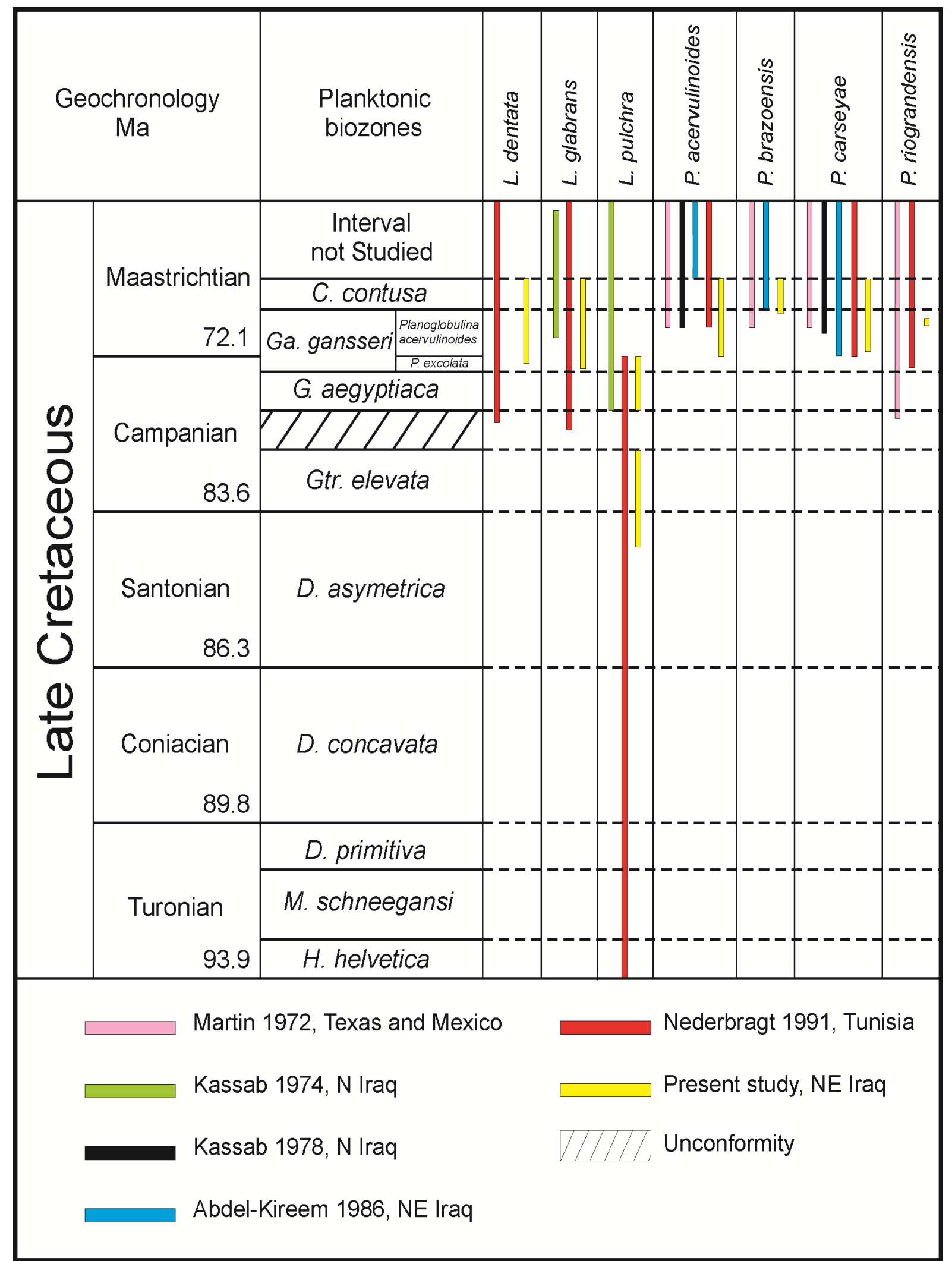

Fig 4: Biostratigraphic ranges of Laeviheterohelix (L.) and Planoglobulina (P.) species recorded in Kurdistan region, NE Iraq and their equivalent ranges in North Africa, Texas and Mexico. Planktonic foraminiferal biozones after Jaff et al. (2015). Time scale adapted from Ogg and Hinnov (2012). Planktonic biozones abbreviations: H. = Helvetoglobotruncana; $M .=$ Marginotruncana $;$ D. = Dicarinella $;$ Gtr. = Globotruncanita $;$ G. = Globotruncana $;$ Ga. = Gansserina P. = Pseudoguembelina; . = Contusotruncana . 
Genus Pseudoguembelina Brönnimann and Brown, 1953

Pseudoguembelina costulata (Cushman, 1938), Plate 4, figs. 4, 5

Gümbelina costulata Cushman, 1938, p. 16, 17, pl. 3, figs. 7-9; Cushman, 1946, p. 108, pl. 46, figs. 10-12.

Pseudoguembelina costulata (Cushman). Brönnimann and Brown, 1953, p. 153, 154, text fig. 5; Montanaro Gallitelli, 1957, p. 139, pl. 31, figs. 21, 22; Pessagno, 1967, p. 266, pl. 79, fig. 1, pl. 88, figs. 8, 9, pl. 90, fig. 3; Govindan, 1972, p. 169, pl. 1, figs. 15, 16; Smith and Pessagno, 1973, p. 24, 25, pl. 6, figs. 1-5; Darmoian, 1975, p. 197 , 198, pl. 3, figs. 1-5; Weiss, 1983, p. 56, pl. 6, figs. 8-10; Abdel-Kireem, 1986, p. 224, pl. 1, fig. 15; Nederbragt, 1989, p. 200, pl. 6, figs. 3-5; Nederbragt, 1991, p. 358, pl. 8, figs. 3, 4; Georgescu, 1995, p. 101, pl. 4, figs. 1-3; Abdel-Kireem et al., 1996b, p. 250, fig. 5 (16); Abramovich et al., 2003, p. 9, pl. II, fig. 12; Abramovich et al., 2011, p. 147, pl. 3, figs. 14, 15 .

-Material. Over 500 specimens from Latest Campanian to Early Maastrichtian samples.

-Dimensions. 50 specimens measured give the following dimensions: height of test $0.20-0.30 \mathrm{~mm}$, width of test $0.12-0.20 \mathrm{~mm}$, height of last chamber $0.06-0.10 \mathrm{~mm}$, width of last chamber $0.08-0.12 \mathrm{~mm}$.

-Remarks. The Kurdistani specimens can be differentiated from material of Psg. excolata (Cushman, 1926) by having a narrow and slender test, and by more closely spaced and finer costae.

-Occurrence. (Latest Campanian-Early Maastrichtian; Fig. 5).

Pseudoguembelina excolata (Cushman, 1926), Plate 4, figs. 6-7 Gümbelina excolata Cushman, 1926, p. 20, pl. 2, fig. 9; White, 1929, p. 34, pl. 4, fig. 7; Cushman, 1938, p. 17, pl. 3, fig. 11; Cushman, 1946, p. 108, pl. 46, fig. 16. Pseudoguembelina excolata (Cushman). Brönnimann and Brown, 1953, p. 153, text figs 1-4; Montanaro Gallitelli, 1957, p. 139, pl. 31, fig. 23; Pessagno, 1967, p. 266, 267, pl. 68, figs. 4, 5, pl. 90, fig. 5; Smith and Pessagno, 1973, p. 25, 26, pl. 6, figs. 610; Darmoian, 1975, p. 198, pl. 2, fig. 20; Abdel-Kireem, 1986, p. 224, pl. 1, fig. 16; Nederbragt, 1989, p. 202, pl. 6, figs. 6, 7; Nederbragt, 1991, p. 360, pl. 8, fig. 5; Georgescu, 1995, p. 101, 102, pl. 4, figs. 4-6; Abdel-Kireem et al., 1996b, p. 250, fig. 5 (17, 18); Abramovich et al., 2003, p. 9, pl. II, fig. 13; Abramovich et al., 2011, p. 147, pl. 3, figs. 16-19.

-Material. Over 100 specimens from Latest Campanian to Early Maastrichtian.

Dimensions. 15 specimens measured give the following dimensions: height of test $0.25-0.30 \mathrm{~mm}$, width of test $0.20-0.28 \mathrm{~mm}$, height of last chamber $0.08-0.10 \mathrm{~mm}$, width of last chamber $0.10-0.13 \mathrm{~mm}$.

-Remarks. Psg. excolata can be differentiated from material of Psg. costulata (Cushman, 1938) in having a wider test, by being triangular in outline, and by possessing more widely spaced and thicker costae.

-Occurrence. (Latest Campanian-Early Maastrichtian; Fig. 5).

Genus Pseudotextularia Rzehak, 1891

Pseudotextularia deformis (Kikoine, 1948), Plate 4, figs. 8-9

Gümbelina striata (Ehrenberg) var. deformis Kikoine, 1948, p. 20, pl. 1, fig. 8. 
Pseudotextularia deformis (Kikoine). Pessagno, 1967, p. 269, pl. 90, fig. 16, pl. 92, figs. 19-21, pl. 97, figs. 16, 17, pl. 98, figs. 15, 17, 18; Smith and Pessagno, 1973, p. 29, pl. 9, figs. 1-4, pl. 10, fig. 1; Kassab, 1978, p. 77, pl. 1, figs. 4, 5; Weiss, 1983, p. 60, 61, pl. 8, figs. 1, 2; Abdel-Kireem, 1986, p. 226, pl. 2, figs. 10-12, pl. 3, fig. 11; Abramovich et al., 2003, p. 13, pl. IV, fig. 1.

-Material. 18 specimens from 13 samples.

-Dimensions. 10 specimens measured give the following dimensions: height of test $0.40-0.45 \mathrm{~mm}$, width of test $0.26-0.35 \mathrm{~mm}$, height of last chamber $0.12-0.13 \mathrm{~mm}$, width of last chamber $0.18-0.22 \mathrm{~mm}$.

-Remarks. The Kurdistani specimens can be distinguished from material of the type species Pst. elegans (Rzehak, 1891) by its broad, triangular outline in side view, chambers that expand slowly in height but rapidly in width, and by its coarser and less massive discontinuous costae and much thicker test wall.

-Occurrence. (Latest Campanian-Early Maastrichtian; Fig. 5).

Pseudotextularia elegans (Rzehak, 1891), Plate 4, figs. 10-11, Plate 5, figs. 17-18 Cuneolina elegans Rzehak, 1891, p. 4.

Gümbelina elegans (Rzehak). White, 1929, p. 34, 35, pl. 4, fig. 8.

Pseudotextularia elegans (Rzehak). Pessagno, 1967, p. 268, 269, pl. 75, figs. 12-17, pl. 85 , figs. 10,11 , pl. 88, figs. 14-16, pl. 89, figs. 10, 11, pl. 97, fig. 18, pl. 98, figs. 19, 20; Govindan, 1972, p. 170, 171, pl. 1, figs. 5, 6, pl. 2, figs. 6, 7; Smith and Pessagno, 1973, p. 30-32, pl. 9, figs. 5-15, pl. 10, figs. 2-6; Darmoian, 1975, p. 199, pl. 3, figs. 16, 17; Frerichs et al., 1975, p. 301, 302, pl. 1, figs. 13, 14; Kassab, 1978, p. 79, pl. 1, figs. 6, 7; Weiss, 1983, p. 61-63, pl. 8, figs. 5-7; Abdel-Kireem, 1986, p. 226, pl. 2, figs. 13-16, pl. 3, figs. 12, 13; Georgescu, 1995, p. 97, pl. 3, figs. 1-3; Abdel-Kireem et al., 1996b, p. 249, fig. 5 (14, 15); Abramovich et al., 2003, p. 13, pl. IV, fig. 2; Abramovich et al., 2011, p. 148, pl. 4, figs. 7, 8.

-Material. Over 500 specimens from Late Campanian to Early Maastrichtian samples. -Dimensions. 50 specimens measured give the following dimensions: height of test $0.30-0.58 \mathrm{~mm}$, width of test $0.15-0.30 \mathrm{~mm}$, height of last chamber $0.12-0.20 \mathrm{~mm}$, width of last chamber $0.10-0.16 \mathrm{~mm}$.

-Remarks. As noted above, Pst. elegans can be distinguished from material of Pst. deformis (Kikoine, 1948) by its narrower outline in side view, chambers that expand rapidly in height but slowly in width, more massive, closely spaced, discontinuous costae, and thinner test wall.

-Occurrence. (Late Campanian-Early Maastrichtian; Fig. 5).

Pseudotextularia nuttalli (Voorwijk, 1937), Plate 4, figs. 12-13

Gümbelina nuttalli Voorwijk, 1937, p. 192, pl. 2, figs. 1-9.

Heterohelix nuttalli (Voorwijk). Darmoian, 1975, p. 192, pl. 1, figs. 4-6.

Pseudotextularia nuttalli (Voorwijk). Kassab, 1978, p. 81, 82, pl. 1, fig. 15; Nederbragt, 1989, p. 204, pl. 8, figs. 2, 3; Nederbragt, 1991, p. 364-366, pl. 10, figs. 4,6 .

-Material. Over 100 specimens from Late Campanian to Early Maastrichtian samples, -Dimensions. 20 specimens measured give the following dimensions: height of test $0.47-0.67 \mathrm{~mm}$, width of test $0.32-0.40 \mathrm{~mm}$, height of last chamber $0.18-0.23 \mathrm{~mm}$, width of last chamber $0.16-0.20 \mathrm{~mm}$. 
-Remarks. In Kurdistan it differs from both Pst. elegans (Rzehak, 1891) and Pst. deformis (Kikoine, 1948) by its wider test in side view, very thin discontinuous costae developed on the surface of the test, and by its low arched aperture.

-Occurrence. (Late Campanian-Early Maastrichtian; Fig. 5).

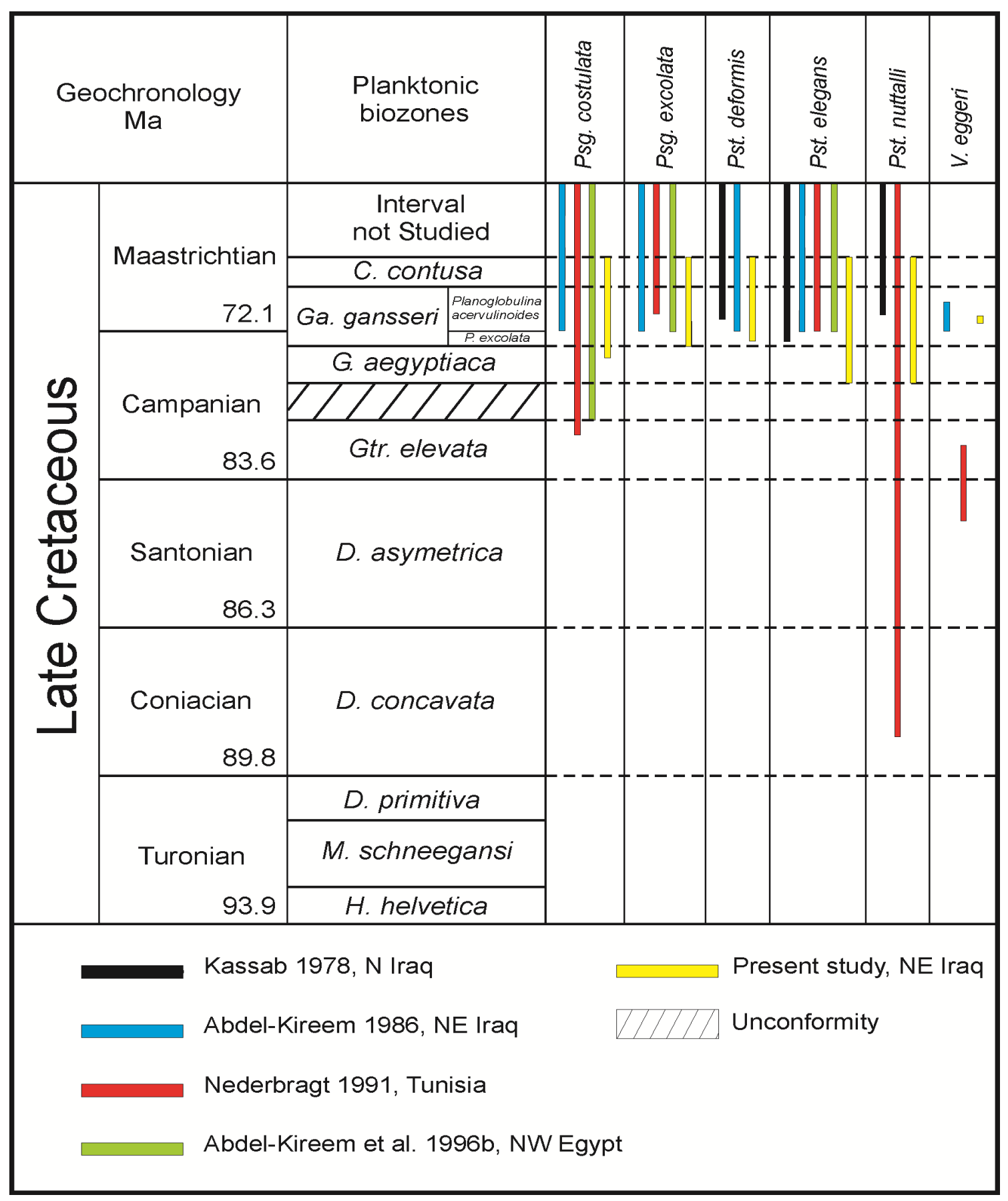

Fig. 5: Biostratigraphic ranges of Pseudoguembelina (Psg.), Pseudotextularia (Pst.) and Ventilabrella $(V$.$) species recorded in Kurdistan region, NE Iraq and their equivalent ranges in$ North Africa. Planktonic foraminiferal biozones after Jaff et al. (2015). Time scale adapted from Ogg and Hinnov (2012). Note that Ventilabrella eggeri, has been reported from an earlier stratigraphic interval in Tunisia by (Nederbragt, 1991). Planktonic biozones abbreviations: $H .=$ Helvetoglobotruncana $;$. = Marginotruncana $;.=$ Dicarinella $;$ Gtr. $=$ Globotruncanita; $G .=$ Globotruncana $; G a .=$ Gansserina $; P .=$ Pseudoguembelina $; C .=$ Contusotruncana. 
Genus Ventilabrella Cushman, 1928

Ventilabrella eggeri Cushman, 1928, Plate 4, figs. 14-15

Ventilabrella eggeri Cushman, 1928, p. 2, pl. 1, figs. 10-12; Cushman, 1938, p. 25, pl. 4, figs. 12-14; Cushman, 1946, p. 111, pl. 47, figs. 17-22; Martin, 1972, p. 85, pl. 1, figs. 6, 7; Darmoian, 1975, p. 202, pl. 4, fig. 13; Weiss, 1983, p. 66, 67, pl. 9, figs. 6-8; Abdel-Kireem, 1986, p. 228, pl. 3, fig. 1; Nederbragt, 1991, p. 369, pl. 12, figs. $5-7$.

-Material. 5 specimens from 3 samples.

-Dimensions. 5 specimens measured give the following dimensions: height of test 0.35-0.38 mm, width of test 0.30-0.37 mm.

-Remarks. The species in Kurdistan is similar to Planoglobulina carseyae (Plummer, 1931), but can be differentiated by its regular arrangement of chambers in the last row of the test, which give a $30^{\circ}$ to $35^{\circ}$ degree angle of inclination.

-Occurrence. (Early Maastrichtian; Fig. 5).

\section{DISCUSSION: ROLE OF HETEROHELICIDAE IN LATE CRETACEOUS BIOSTRATIGRAPHY}

The studied heterohelicids are characterised by increasing numerical abundance, species diversity and intraspecific variability from the Turonian to the Maastrichtian. Heterohelicids are abundant in Kurdistan, except during the Early Turonian, where only two species, Planoheterohelix moremani and Pl. globulosa are recorded within the Helvetoglobotruncana helvetica Total Range Zone (see Fig. 3). From the midTuronian to mid-Santonian, heterohelicids are dominated by $P l$. globulosa and $P l$. reussi, and this is the case also in Tunisia (Nederbragt, 1991), Egypt (Abdel-Kireem et al., 1996a, b) and Syria (Pecimotika et al., 2014). Due to long temporal ranges for these two species; their biostratigraphical utility in the Turonian to Santonian is only general where other index planktonic species of Dicarinella or Marginotruncana are absent: because of the low diversity of heterohelicids, Abdel-Kireem et al. (1996a) recognised only one heterohelicid biozone ( $P l$. reussi Biozone) for the Turonian to mid-Santonian interval in Egypt. In the late Santonian the diversity of heterohelicids increased towards the top of the Dicarinella asymetrica Total Range Zone (see Fig. 3). Both Pl. planata and L. pulchra have their first occurrence in the Late Santonian, but the latter species has an earlier stratigraphic occurrence elsewhere (Darmoian, 1975; Odébòdé, 1982; Nederbragt, 1991; Georgescu, 2009). Nevertheless, Pl. planata defines the Late Santonian in Tunisia (Nederbragt, 1991), Egypt (Abdel-Kireem et al., 1996b), and in a number of DSDP and ODP sites around the world (Georgescu et al., 2008), and is therefore important for regional correlation at the level of the Dicarinella asymetrica Total Range Zone (see Fig. 3). Most other biserial heterohelicid species have their first occurrence in the Late Campanian, at the level equivalent to the Globotruncana aegyptiaca and Gansserina gansseri interval biozones, and their first occurrences are thus a proxy for these biozones where keeled planktonic foraminifera are rare or absent. Taxa appearing at this level include B. punctulata, H. striata, $H$. ultimatumida, Pst. elegans, Psg. costulata and Psg. excolata (Figs 3 and 5). The first occurrences of most of the above species are diachronous globally (Kassab, 1974, 1978; Abdel-Kireem, 1986; Nederbragt, 1989; 1991; Abdel-Kireem et al., 1996b; see Figs 3 and 5). However, Pst. elegans and Psg. excolata can be used to define the Late 
and Latest Campanian in Kurdistan and other regions (e.g., Martin, 1972 in the USA; Robaszynski, 1998 for several regions; Güray, 2006 for Turkey; Pecimotika et al., 2014 for Syria; Jaff et al., 2015 for Kurdistan). The maximum species diversity and abundance of heterohelicids in Kurdistan is recorded in the Early Maastrichtian part of the Gansserina gansseri interval Biozone, as is the case for Tunisia and Egypt (Nederbragt, 1991; Abdel-Kireem et al., 1996b). The multiserial heterohelicids in Kurdistan, including species of Praegublerina, Gublerina and Planoglobulina, are recorded in the Early Maastrichtian that can be used to define the CampanianMaastrichtian boundary, or the Early Maastrichtian at most Tethys Ocean sites (Fig. 4). The First Appearance Datum (FAD) of Planoglobulina acervulinoides defines the Campanian-Maastrichtian boundary in Kurdistan (Jaff et al., 2014, 2015) and other regions (e.g., Robaszynski, 1998; Güray, 2006). According to Ogg and Hinnov (2012 and references therein) its FAD is estimated at $72.97 \mathrm{Ma}$, which is very close to the age datum assigned to the Campanian-Maastrichtian boundary at $72.1 \mathrm{Ma}$ (Ogg and Hinnov op. cit.). In some areas such as Iran and Tunisia, the FAD of Planoglobulina carseyae defines the Campanian-Maastrichtian boundary instead of Planoglobulina acervulinoides (see Li et al., 1999; Darvishzad and Abdolalipour, 2009). However, the species is very rare in Kurdistan and occur intermittently (see Fig. 4).

\section{CONCLUSIONS}

The biostratigraphical importance and systematic palaeontology of Early Turonian to Early Maastrichtian Heterohelicidae planktonic foraminifera from Kurdistan are described. Some 24 species from 11 genera are recorded. The Early Turonian-Early Maastrichtian succession of Kurdistan yields diverse heterohelicid species which can be used for planktonic foraminiferal biozonation when the index species of dicarinellids, marginotruncanids and globotruncanids are absent. The maximum species diversity and abundance of Heterohelicidae in Kurdistan is recorded in the Early Maastrichtian, which is consistent with the global record. The first occurrences of the flaring heterohelicids with more than two chambers per row (e.g. Praegublerina, Gublerina and Planoglobulina) are recorded in the Earliest Maastrichtian; this can be used to define the Campanian-Maastrichtian boundary throughout Tethys Ocean Cretaceous successions.

\section{ACKNOWLEDGEMENTS}

RBNJ send thanks to Rob Wilson for his help during imaging of microfossils, and Colin Cunningham for thin section preparation at the University of Leicester, UK.

\section{REFERENCES}

Abawi, T.S., and Hammoudi, R.A., 1997. Foraminiferal biostratigraphy of the Kometan and Gulneri Formations (Upper Cretaceous) in Kirkuk area, north of Iraq. Iraqi Geological Journal, 30:139-146.

Abdel-Kireem, M.R., 1986. Planktic foraminifera and stratigraphy of the Tanjero Formation (Maastrichtian), northeastern Iraq. Micropaleontology, 32:215-231.

Abdel-Kireem, M.R., Schrank, E., Samir, A.M., and Ibrahim, M.I.A., 1996a. Cretaceous palaeoecology, palaeogeography and palaeoclimatology of the northern Western Desert, Egypt. Journal of African Earth Sciences, 22:93-112. 
Abdel-Kireem, M.R., Ibrahim, M.I.A., and Samir, A.M., 1996b. Late Cretaceous Heterohelicidae ( foraminifera) from the northern part of the Western Desert of Egypt. Neues Jahrbuch für Geologie und Paläontologie, Abhandlungen, 200:237257.

Abramovich, S., and Keller, G., 2002. High stress late Maastrichtian paleoenvironment: inference from planktic foraminifera in Tunisia. Palaeogeography, Palaeoclimatology, Palaeoecology, 178:145-164.

Abramovich, S., and Keller, G., 2003. Planktic foraminiferal response to the latest Maastrichtian abrupt Warm Event: A case study from South Atlantic DSDP site 525A. Marine Micropaleontology, 48:225-249.

Abramovich, S., Keller, G., Adatte, T., Stinnesbeck, W., Hottinger, L., Stueben, D., Berner, Z., Ramanivosoa, B., and Randriamanantenasoa, A., 2002. Age and paleoenvironment of the Maastrichtian to Paleocene of the Mahajanga Basin, Madagascar: a multidisciplinary approach. Marine Micropaleontology, 47:17-70.

Abramovich, S., Keller, G., Stuben, D., and Berner, Z., 2003. Characterization of late Campanian and Maastrichtian Planktic foraminiferal depth habitats and vital activities based on stable isotopes. Palaeogeography, Palaeoclimatology, Palaeoecology, 202:1-29.

Abramovich, S., Yovel-Corem, S., Almogi-Labin, A., and Benjamini, C., 2010. Global climate change and foraminiferal response in the Maastrichtian. Paleoceanography, 25:PA2201.

Abramovich, S., Keller, G., Berner, Z., Cymbalista, M., and Rak, C., 2011. Maastrichtian foraminiferal biostratigraphy and paleoenvironment of Brazos River, Falls County, Texas, USA. Society for Sedimentary Geology, Special Publication, 100:123-156.

Al-Banna, N.Y., 2010. Sequence stratigraphy of the Late Campanian-Early Maastrichtian Shiranish Formation, Jabal Sinjar, northwestern Iraq. GeoArabia, 15:31-44.

Al-Jassim, J.A., Al-Sheikhly, S.S.J., and Al-Tememmy, F.M., 1989. Biostratigraphy of the Kometan Formation (Late Turonian-Early Campanian) in Northern Iraq. Journal of the Geological Society of Iraq, 22:53-60.

Al-Sheikhly, S.S.J., Al-Jassim, J.A., and Al-Tememmy, F.M.D., 1989. Some new species of benthonic foraminifera from the Kometan Formation (Upper Cretaceous) of northern Iraq. Journal of the Geological Society of Iraq, 22:61-67.

Ameen, F.A., and Gharib, H., 2014. Biostratigraphy of the Tethyan Cretaceous successions from northwestern Zagros fold-thrust belt, Kurdistan region, NE Iraq. Arabian Journal of Geosciences, 7:2689-2710.

Aqrawi, A.A.M., Goff, J.C., Horbury, A.D., and Sadooni, F.N., 2010. The petroleum geology of Iraq. Scientific Press, Beaconsfield, UK, 424 pp.

Brönnimann, P., and Brown, N.K.JR., 1953. Observations on some Planktic Heterohelicidae from the Upper Cretaceous of Cuba. Contributions from the Cushman Foundation for Foraminiferal Research, 4:150-156.

Brotzen, F., 1936. Foraminifern aus dem schwedischen untersten Senon von Eriksdal in Schonen. Sveriges Geologiska Undersokning, 30:206 pp.

Brown, N.K.JR., 1969. Heterohelicidae Cushman, 1927, amended, a Cretaceous Planktic foraminiferal family. Proceedings of the First International Conference on Planktic Microfossils, Geneva, 2:21-67. 
Buday, T., 1980. The Regional Geology of Iraq: Stratigraphy and Palaeogeography. State Organisation for Minerals Library, Baghdad, Iraq, 445 pp.

Caron, M., 1985. Cretaceous Planktic foraminifera. In: Bolli, H.M., Saunders, J.B., Perch-Nielsen, K. (Eds.). Plankton stratigraphy. Cambridge University Press, Cambridge, 17-86.

Cushman, J.A., 1926. Some foraminifera from the Mendez Shale of eastern Mexico. Contributions from the Cushman Laboratory for Foraminiferal Research, 2:1626.

Cushman, J.A., 1927. Some new genera of the foraminifera. Contributions from the Cushman Laboratory for Foraminiferal Research, 3:71-81.

Cushman, J.A., 1928. Additional genera of the foraminifera. Contributions from the Cushman Laboratory for Foraminiferal Research, 4:1-8.

Cushman, J.A., 1938. Cretaceous species of Gümbelina and related genera. Contributions from the Cushman Laboratory for Foraminiferal Research, 14:228.

Cushman, J.A., 1946. Upper Cretaceous foraminifera of the Gulf coastal region of the United States and adjacent areas. Unites States Geological Survey, Professional Paper, 206:1-241.

Darmoian, S.A., 1975. Planktic foraminifera from the Upper Cretaceous of Southeastern Iraq: Biostratigraphy and systematics of the Heterohelicidae. Micropaleontology, 21:185-214.

Darvishzad, B., and Abdolalipour, S., 2009. Campanian and Maastrichtian biostratigraphy and paleoenvironment in Jorband section, North of Iran. Journal of Sciences, Islamic Republic of Iran, 20:23-39.

de Klasz, I., 1953. On the foraminiferal genus Gublerina Kikoine. Geologica Bavarica, 17:245-251.

de Klasz, I., de Klasz, S., and Saint-Marc, P., 1995. Heterohelicids from the Turonian of Senegal (West Africa) with particular emphasis on Heterohelix americana (Ehrenberg). Micropaleontology, 41:359-368.

Delage, Y., and Hérouard, E., 1896. Traite de zoologie concrete. Tome I: La cellule et les protozoaires. Paris, Schleicher Freres, 584 pp.

Egger, J.G., 1899. Foraminiferen und Ostrakoden aus den Kreidemergeln der oberbayerischen Alpen. Abhandlungen der Mathematisch-Physikalischen Klasse der Königlich Bayerischen Akademie der Wissenschaften, München, 21:3-230.

Ehrenberg, C.G., 1840. Uber die Bildung der Kreidefelsen und des Kreidemergels durch unsichtbare Organismen. Abhandlungen der Königlich Preussischen Akademie der Wissenschaften, Berlin, 59-147.

Ehrenberg, C G., 1843. Verbreitung und Einfluss des mikroskopischen Lebens in Sudund Nord Amerika. Abhandlungen der Königlich Preussischen Akademie der Wissenschaften, Berlin, 1:291-446.

Eichwald, C.E., 1830. Zoologia specialis. Vilnae: D.E. Eichwaldus, 2:1-323.

Ellis, B.F., and Messina, A.R., 1940. Catalogue of Foraminifera. American Museum of Natural History, New York.

Faris, M., Jaff, R.B.N., and Farouk, S., 2019. Calcareous nannofossil biostratigraphy and bio-events of the Coniacian-lower Campanian succession in the Kurdistan region, northeastern Iraq. Arabian Journal of Geosciences, 12:153. 
Farouk, S., Thibault, N., Jaff, R.B.N., Faris, M., Ahmad, F., and Khashaba, A., 2018. An integrated study of upper Campanian-lower Maastrichtian carbon isotopes and calcareous plankton biostratigraphy of the Kurdistan Region, northeastern Iraq. Cretaceous Research, 82:64-80.

Frerichs, W.E., Atherton, C.C., and Shive, P.N., 1975. Planktic foraminifera from the chalky members of the Niobrara Formation, Centennial Valley, Wyoming. Journal of Foraminiferal Research, 5:294-312.

Georgescu, M.D., 1995. Upper Cretaceous Heterohelicidae in the Romanian Black Sea offshore. Revista Española de Micropaleontologia, XXVII:91-106.

Georgescu, M.D., 2007. Taxonomic re-evaluation of the Late Cretaceous serial Planktic foraminifer Gümbelina punctulata Cushman, 1938 and related species. Revista Española de Micropaleontología, 39:155-167.

Georgescu, M.D., 2009. Taxonomic revision and evolutionary classification of the biserial Cretaceous foraminiferal genus Laeviheterohelix Nederbragt, 1991. Revista Mexicana de Ciencias Geológicas, 26:315-334.

Georgescu, M.D., and Abramovich, S., 2008. Taxonomic revision and phylogenetic classification of the Late Cretaceous (Upper Santonian-Maastrichtian) serial Planktic foraminifera (Family Heterohelicidae Cushman, 1927) with peripheral test wall flexure. Revista Española de Micropaleontología, 40:97-114.

Georgescu, M.D., and Huber, B.T., 2009. Early evolution of the Cretaceous serial foraminifera (late Albian-Cenomanian). Journal of Foraminiferal Research, 39:335-360.

Georgescu, M.D., Saupe, E.E., and Huber B.T., 2008. Morphometric and stratophenetic basis for phylogeny and taxonomy in Late Cretaceous gublerinid Planktic foraminifera. Micropaleontology, 54:397-424.

Govindan, A., 1972. Upper Cretaceous Planktic foraminifera from the Pondicherry area, south India. Micropaleontology, 18:160-193.

Güray, A., 2006. Campanian-Maastrichtian Planktic foraminiferal investigation and biostratigraphy (Kokaksu section, Bartin, NW Anatolia): Remarks on the Cretaceous paleoceanography based on quantitative data. Unpublished MSc Thesis, Middle East Technical University, Turkey, 244 pp.

Haddad, S.N.S., and Amin, M.A., 2007. Mid-Turonian-early Campanian sequence stratigraphy of northeast Iraq. GeoArabia, 12:135-176.

Hammoudi, R.A., and Abawi, T.S., 2006. Foraminiferal biostratigraphy of the Turonian-Early Campanian depositional subcycle from selected oil wells in Iraq. Anuário do instituto de Geociências, 29:651.

Haynes, S.J., Huber, B.T., and MacLeod, K.G., 2015. Evolution and phylogeny of mid-Cretaceous (Albian-Coniacian) biserial foraminifera. Journal of Foraminiferal Research, 45:42-81.

Huber, B.T., Macleod, K.G., and Tur, N.A., 2008. Chronostratigraphic framework for Upper Campanian-Maastrichtian sediments on the Blake Nose (subtropical North Atlantic). Journal of Foraminiferal Research, 38:162-182.

Jaff, R.B.N., and Lawa, F.A., 2019. Palaeoenvironmental signature of the Late Campanian-Early Maastrichtian benthonic foraminiferal assemblages of Kurdistan, Northeast Iraq. Journal of African Earth Sciences, 151:255-273. 
Jaff, R.B.N., Williams, M., Wilkinson, I.P., Lawa, F., Lee, S., and Zalasiewicz, J., 2014. A refined foraminiferal biostratigraphy for the Late Campanian-Early Maastrichtian succession of northeast Iraq. GeoArabia, 19:161-180.

Jaff, R.B.N., Wilkinson, I.P., Lee, S., Zalasiewicz, J., Lawa, F., and Williams, M., 2015. Biostratigraphy and palaeoceanography of the early Turonian-early Maastrichtian Planktic foraminifera of northeast Iraq. Journal of Micropalaeontology, 34:105-138.

Jassim, S.Z., and Goff, J.C., 2006. Geology of Iraq. Brno, Czech Republic, Dolin, Prague and Moravian Museum, $341 \mathrm{pp}$.

Kaddouri, N., 1982. Late Turonian-Early Campanian sediments in Iraq. Journal of the Geological Society of Iraq, 15:9-18.

Kassab, I.I.M., 1973. Planktic foraminiferida of the Shiranish Formation type locality (Northern Iraq). Journal of the Geological Society of Iraq, Vol. 6, p. 100-109.

Kassab, I.I.M., 1974. The genus Heterohelix (Foraminiferida) from Northern Iraq. Journal of the Geological Society of Iraq, VII:75-94.

Kassab, I.I.M., 1978. The genera Pseudotextularia and Ventilabrella (Foraminiferida) from Northern Iraq. Annales des Mines et de la Géologie, 28:73-89.

Kennedy, W.J., and Lunn, G., 2000. Upper Campanian (Cretaceous) ammonites from the Shiranish Formation, Djebel Sinjar, northwest Iraq. Journal of Paleontology, 7:464-473.

Kikoine, J., 1948. Les Heterohelicidae du Cretace superieur pyreneen. Bulletin de la Société Géologique de France, 18:15-35.

Lawa, F.A., Koyi, H., and Ibrahim, A.O., 2013. Tectono-stratigraphic evolution of the Northwestern segment of Zagros fold-thrust belt, Kurdistan, NE Iraq. Journal of Petroleum Geology, 36:75-96.

Lawa F.A., Al-Karadakhi, A.I., and Ismail, K.. M., 2017. An interfingering of the upper Cretaceous rocks from Chwarta-Mawat region, NE Iraq. Iraqi Bulletin of Geology and Mining, 13:15-26.

Lawa, F.A., 2018. Late Campanian-Maastrichtian sequence stratigraphy from Kurdistan foreland basin, NE Iraq. Journal of Petroleum Exploration and Production Technology, 8:713-732.

Omar, A.A., Lawa F. A., and Sulaiman, S.H., 2015. Tectonostratigraphic and structural imprints from balanced sections across the north-western Zagros foldthrust belt, Kurdistan region, NE Iraq. Arabian Journal of Geosciences, 8:81078129

Li, L., and Keller, G., 1998a. Maastrichtian climate, productivity and faunal turnovers in foraminifera in South Atlantic DSDP Sites 525A and 21. Marine Micropaleontology, 33:55-86.

Li, L., and Keller, G., 1998b. Maastrichtian diversification of foraminifera at El Kef and Elles, Tunisia. Eclogae Geologicae Helvetiae, 91:75-102.

Li, L., and Keller, G., 1999. Variability in Late Cretaceous climate and deep water: Evidence from stable isotopes. Marine Micropaleontology, 161:171-190.

Li, L., Keller, G., and Stinnesbeck, W., 1999. The Late Campanian and Maastrichtian in northwestern Tunisia: palaeoenvironmental inferences from lithology, macrofauna and benthic foraminifera. Cretaceous Research, 20:231-252.

Loeblich, A.R. JR., 1951. Coiling in the Heterohelicidae. Contributions from the Cushman Foundation for Foraminiferal Research, 2:106-111. 
Martin, S.E., 1972. Re-examination of the Upper Cretaceous Planktic foraminiferal genera Planoglobulina Cushman and Ventilabrella Cushman. Journal of Foraminiferal Research, 2:73-92.

Masters, B.A., 1977. Mesozoic planktonic foraminifera. A world-wide review and analysis. In: Ramsey, A.T.S. (Ed.). Oceanic Micropaleontology. Academic Press, London, 1:301-731.

Masters, B.A., 1980. Re-evaluation of selected types of Ehrenberg's Cretaceous planktonic foraminifera. Eclogae Geologicae Helvetiae, 73:95-107.

Montanaro Gallitelli, E., 1957. A revision of the foraminiferal family Heterohelicidae. Bulletin United States National Museum, 215:133-154.

Nederbragt, A.J., 1989. Maastrichtian Heterohelicidae (Planktic foraminifera) from the North West Atlantic. Journal of Micropalaeontology, 8:183-206.

Nederbragt, A.J., 1991. Late Cretaceous biostratigraphy and development of Heterohelicidae ( foraminifera). Micropaleontology, 37:329-372.

Odébòdé, M.O., 1982. Senonian Heterohelicidae from the Calabar Flank, southeastern Nigeria. Revista Española de Micropaleontología, XIV:231-246.

Ogg, J.C., and Hinnov, L.A., 2012. Cretaceous. In: Gradstein, F.N., Ogg, J.G., Schmitz, M., Ogg, G. (Eds.). The Geologic time scale 2012. Elsevier, 793-853.

Pecimotika, G., Tešović, B.C., and Fućek, V.P., 2014. Planktic foraminiferal biostratigraphy and paleoecology of Upper Cretaceous deposits from the Palmyride Region, Syria. Geologia Croatica, 67:87-110.

Pessagno, E.A.JR., 1967. Upper Cretaceous Planktic foraminifera from the western Gulf Coastal Plain. Palaeontographica Americana, 5:245-445.

Plummer, H.J., 1931. Some Cretaceous foraminifera in Texas. Texas University Bulletin, 3101:109-203.

Robaszynski, F., 1998. Planktic foraminifera-Upper Cretaceous, Chart of Cretaceous Biochronostratigraphy. In: De Graciansky, P.C., Hardenbol, J., Vail, P.R. (Eds.). Mesozoic and Cenozoic Sequence Stratigraphy of European Basins. Society for Sedimentary Geology, Special Publication, 60:782.

Robaszynski, F., and Caron, M., 1995. Cretaceous Planktic foraminifera: comments on the Europe-Mediterranean zonation. Bulletin de la Société Géologique de France, 166:681-692.

Rzehak, A., 1891. Die Foraminiferen-Fauna der alttertiaren Ablagerungen von Brunderndorf in Niederosterreich, mit Berucksichtigung des angeblichen Kreidevorkommens von Leitzersdorf. Annalen des naturhistorischen Hofmusems, Wein, 6:1-12.

Sharbazheri, K.M.I., 2008. Biostratigraphy and paleoecology of Cretaceous/Tertiary boundary in the Sulaimani region, Kurdistan, NE-Iraq. Unpublished PhD Dissertation, University of Sulaimani, Iraq, $197 \mathrm{pp}$.

Sissakian, V.K., 2000. Geological map of Iraq, Sheets No.1, Scale 1:1000000. State establishment of geological survey and mining. GEOSURV, Baghdad, Iraq.

Smith, C.C., and Pessagno, E.A., 1973. Planktic foraminifera and stratigraphy of the Corsicana Formation (Maestrichtian) north-central Texas. Contributions from the Cushman Foundation for Foraminifera Research, Special Publication, 12:5-68.

Stenestad, E., 1968. Three new species of Heterohelix Ehrenberg from the Upper Senonian of Denmark. Meddelelser fra Dansk geologisk Forening, 18:64-70. 
van Bellen, R.C., Dunnington, H.V., Wetzel, R., and Morton, D.M., 2005. Lexique Stratigraphique International. Centre National Recherche Scientifique, 333 pp. Reprinted by permission of CNRS by Gulf PetroLink, Bahrain in 2005 (original print 1959).

Voorwijk, G.H., 1937. Foraminifera from the Upper Cretaceous of Habana, Cuba. Koninklijke Nederlandse Akademie van Wetenschappen, 40:190-198.

Weiss, W., 1983. Heterohelicidae (seriale planktonische Foraminiferen) der tethyalen Oberkreide (Santon bis Maastricht). Geologisches Jahrbuch, Hannover, 72, 96 pp.

White, M.P., 1929. Some index foraminifera from the Tampico Embayment area of Mexico. Journal of Paleontology, 3:30-58.

Wonders, A.A.H., 1980. Middle and Late Cretaceous Planktic foraminifera of the western Mediterranean area. Utrecht Micropaleontological Bulletins, 24:1-158.

\section{Plate 1: Foraminifera of the Shiranish Formation, Scale bars $100 \mu \mathrm{m}$}

Figs. 1-3: Praegublerina acuta (de Klasz). Figs. 1, 2, Dokan section, sample number DSH-117; Fig. 3, Azmer section, sample number ASH-50.

Figs. 4-6: Gublerina cuvillieri Kikoine. Figs. 4, 5, Dokan section, sample number DSH-117, Fig. 6, Azmer section, sample number ASH-62.

Figs. 7-9: Planoheterohelix globulosa (Ehrenberg). Figs. 7, 8, Dokan section, sample number DSH-64; Fig. 9a, Azmer section, sample number ASH-40; Fig. 9b, discontinuous costae on the surface of ultimate chamber of $\mathrm{Pl}$. globulosa.

Figs. 10-12: Planoheterohelix planata (Cushman). Fig. 10, Dokan section, sample number DSH-117; Figs. 11, 12, Azmer section, sample number ASH-30.

Figs. 13-15: Planoheterohelix reussi (Cushman). Fig. 13, Dokan section, sample number DSH-64; Figs. 14, 15, Azmer section, sample number ASH-05.

\section{Plate 2: Foraminifera of the Shiranish Formation, Scale bars $100 \boldsymbol{\mu m}$}

Figs. 1, 2: Heterohelix semicostata (Cushman). Fig. 1, Dokan section, sample number DSH-80; Fig. 2, Dokan section, sample number DSH-88.

Figs. 3, 4: Heterohelix striata (Ehrenberg). Fig. 3, Dokan section, sample number DSH-90; Fig. 4a, Dokan section, sample number DSH-117; Fig. 4b, continuous costae on the surface of ultimate chamber of $H$. striata.

Figs. 5, 6: Heterohelix ultimatumida (White). Fig. 5, Azmer section, sample number ASH-48; Fig. 6, Dokan section, sample number DSH-117.

Figs. 7-9: Braunella punctulata (Cushman). Fig. 7, Azmer section, sample number ASH-09; Fig. 8, Azmer section, sample number ASH-10; Fig. 9, Dokan section, sample number DSH-45.

Figs. 10-12: Paraspiroplecta navarroensis (Loeblich). Fig. 10, Dokan section, sample number DSH-105; Fig. 11, Dokan section, sample number DSH-117; Fig. 12, Azmer section, sample number ASH-58.

Figs. 13-15: Laeviheterohelix dentata (Stenestad). Fig. 13, Dokan section, sample number DSH-82, Fig. 14, Dokan section, sample number DSH-117; Fig. 15, Azmer section, sample number ASH-50. 


\section{Plate 3: Foraminifera of the Shiranish Formation Scale bars $100 \mu \mathrm{m}$}

Figs. 1-3: Laeviheterohelix glabrans (Cushman). Figs. 1, 2, Dokan section, sample number DSH-110; Fig. 3, Azmer section, sample number ASH-60.

Figs. 4, 5: Laeviheterohelix pulchra (Brotzen). Figs. 4, Dokan section, sample number DSH-60, Figs. 5, Dokan section, sample number DSH-64. Figs. 4b and 5b side views of $L$. pulchra show well developed flanges in the last pair of chambers.

Figs. 6-8: Planoglobulina acervulinoides (Egger). Fig. 6, Azmer section, sample number ASH-60, Fig. 7, Dokan section, sample number DSH-88; Fig. 8, Dokan section, sample number DSH-117.

Figs. 9-11: Planoglobulina brazoensis Martin. Figs. 9, 10, Dokan section, sample number DSH-117, Fig. 11, Azmer section, sample number ASH-52.

Fig. 12: Planoglobulina carseyae (Plummer). Dokan section, sample number DSH115.

\section{Plate 4: Foraminifera of the Shiranish Formation, Scale bars $100 \mu \mathrm{m}$}

Figs. 1, 2: Planoglobulina carseyae (Plummer). Fig. 1, Dokan section, sample number DSH-117; Fig. 2, Azmer section, sample number ASH-47.

Fig. 3: Planoglobulina riograndensis (Martin). Dokan section, sample number DSH117.

Figs. 4, 5: Pseudoguembelina costulata (Cushman). Fig. 4, Dokan section, sample number DSH-86; Fig. 5, Azmer section, sample number ASH-55.

Figs. 6, 7: Pseudoguembelina excolata (Cushman). Fig. 6, Azmer section, sample number ASH-42; Fig. 7, Dokan section, sample number DSH-70.

Figs. 8, 9: Pseudotextularia deformis (Kikoine). Fig. 8, MPK14520, Azmer section, sample number ASH-54; Fig. 9, Azmer section, sample number ASH-60.

Figs. 10, 11: Pseudotextularia elegans (Rzehak). Fig. 10, Azmer section, sample number ASH-02; Fig. 11, Dokan section, sample number DSH-05.

Figs. 12, 13: Pseudotextularia nuttalli (Voorwijk). Fig. 12, Dokan section, sample number DSH-20; Fig. 13, Azmer section, sample number ASH-55.

Figs. 14, 15: Ventilabrella eggeri Cushman. Fig. 14, Dokan section, sample number DSH-90; Fig. 15, Dokan section, sample number DSH-92.

\section{Plate 5: Foraminifera of the Kometan and Shiranish formations, Scale bar as for Figure 1 Plate 5}

Figs. 1-4: Planoheterohelix globulosa (Ehrenberg). Fig. 1, Azmer section, sample number AK-17; Fig. 2, Dokan section, sample number DK-24; Fig. 3, Dokan section, sample number DK-74; Fig. 4, Dokan section, sample number DSH-48.

Figs. 5, 6: Planoheterohelix moremani (Cushman). Fig. 5, Dokan section, sample number DK-12; Fig. 6, Dokan section, sample number DK-2.

Fig. 7: Planoheterohelix planata (Cushman). Dokan section, sample number DK-36.

Figs. 8, 9: Planoheterohelix reussi (Cushman). Fig. 8, Azmer section, sample number AK-35; Fig. 9, Dokan section, sample number DK-34.

Fig. 10: Braunella punctulata (Cushman). Azmer section, sample number ASH-57.

Figs. 11, 12: Laeviheterohelix dentata (Stenestad). Fig. 11, Dokan section, sample number DSH-82, Fig. 12, Dokan section, sample number DSH-117.

Fig. 13: Laeviheterohelix pulchra (Brotzen). Dokan section, sample number DK-68. 
Figs. 14, 15: Planoglobulina acervulinoides (Egger). Fig. 14, MPK14540, Azmer section, sample number ASH-59; Fig. 15, Dokan section, sample number DSH88.

Fig. 16: Planoglobulina brazoensis Martin. Azmer section, sample number ASH-60.

Figs. 17, 18: Pseudotextularia elegans (Rzehak). Fig. 17, Dokan section, sample number DSH-48; Fig. 18, Azmer section, sample number ASH-15.

\section{PLATE 1}

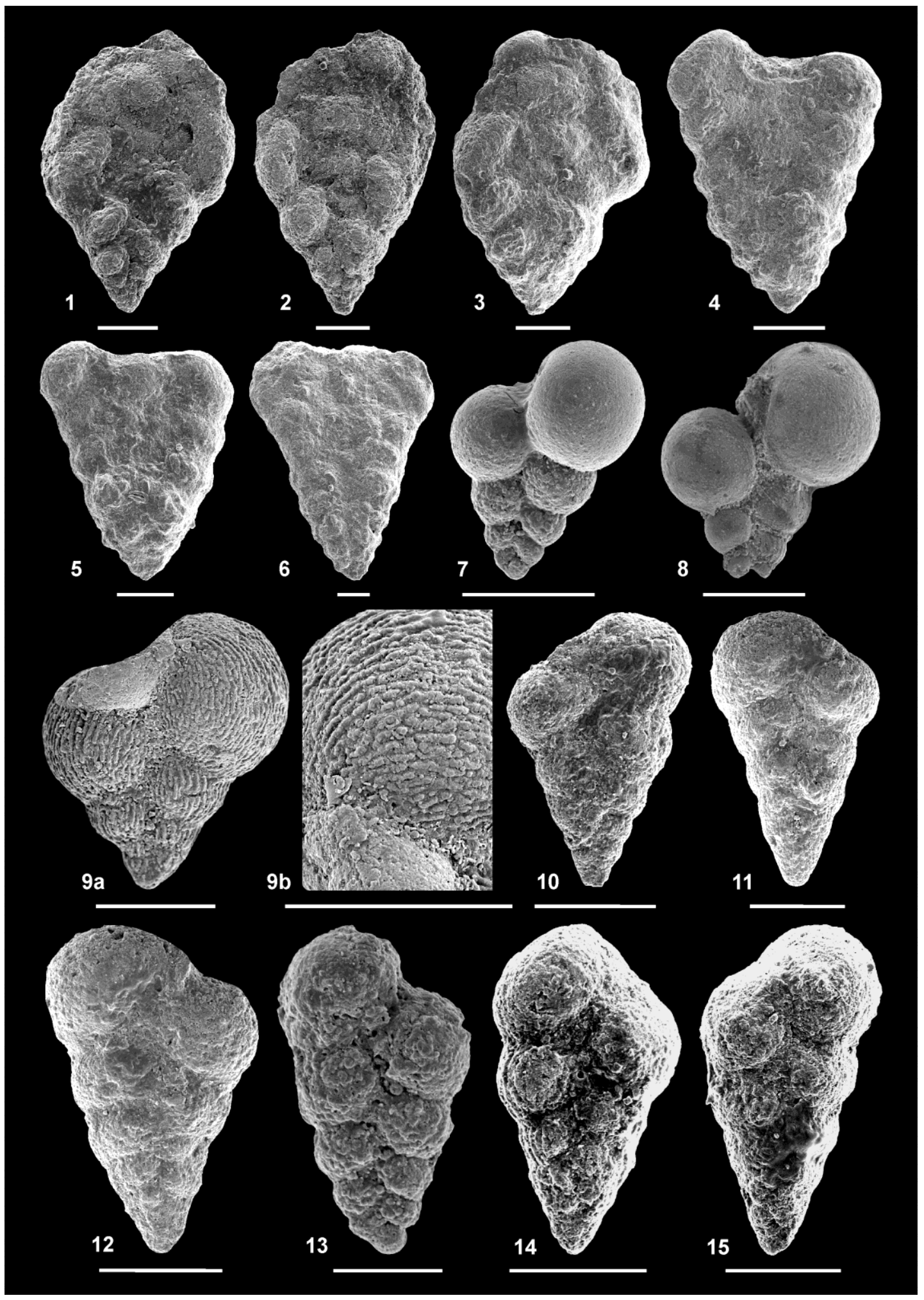




\section{PLATE 2}

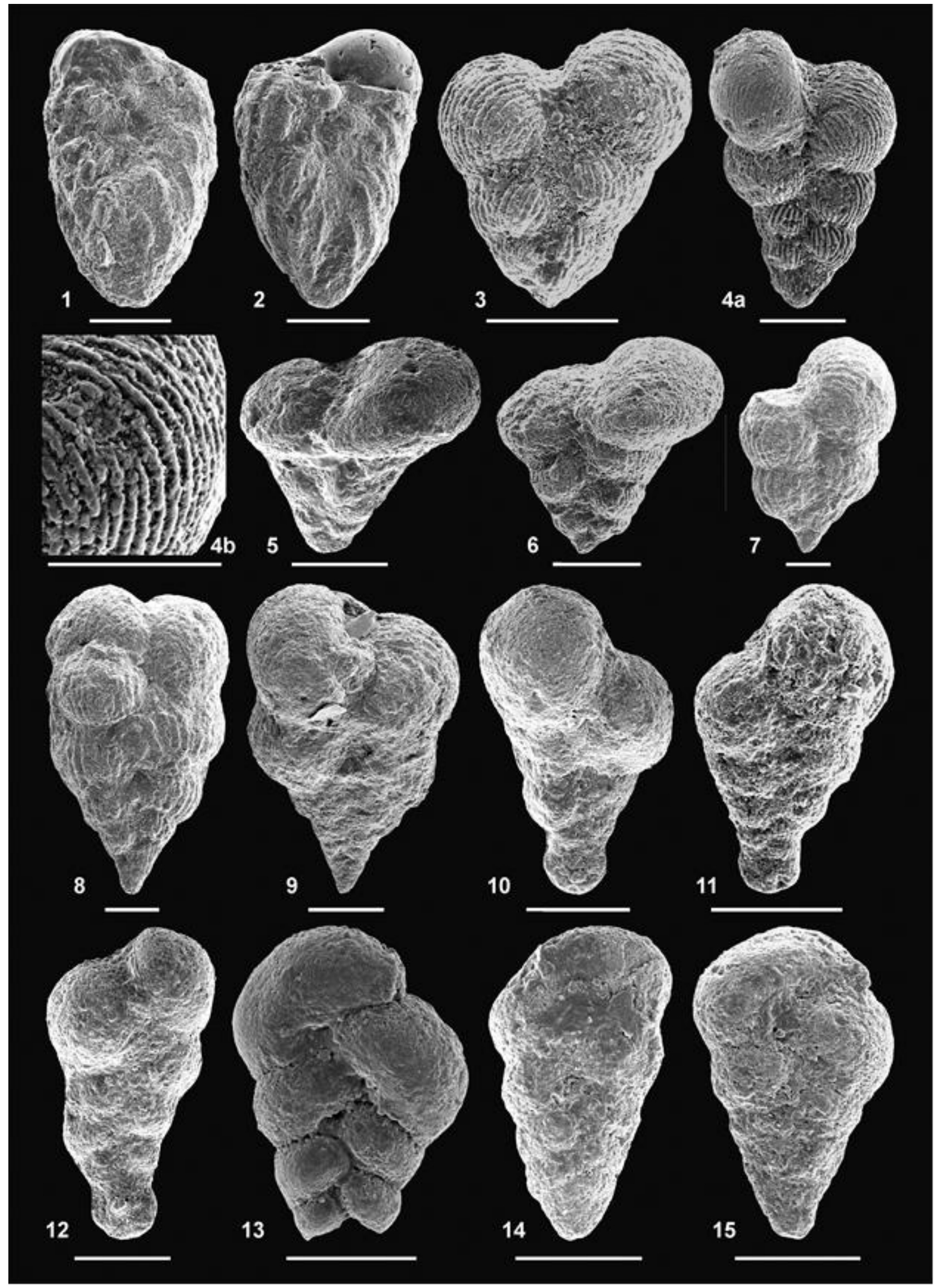


61 Biostratigraphy and Systematic Palaeontology of Late Cretaceous Heterohelicidae.....

\section{PLATE 3}

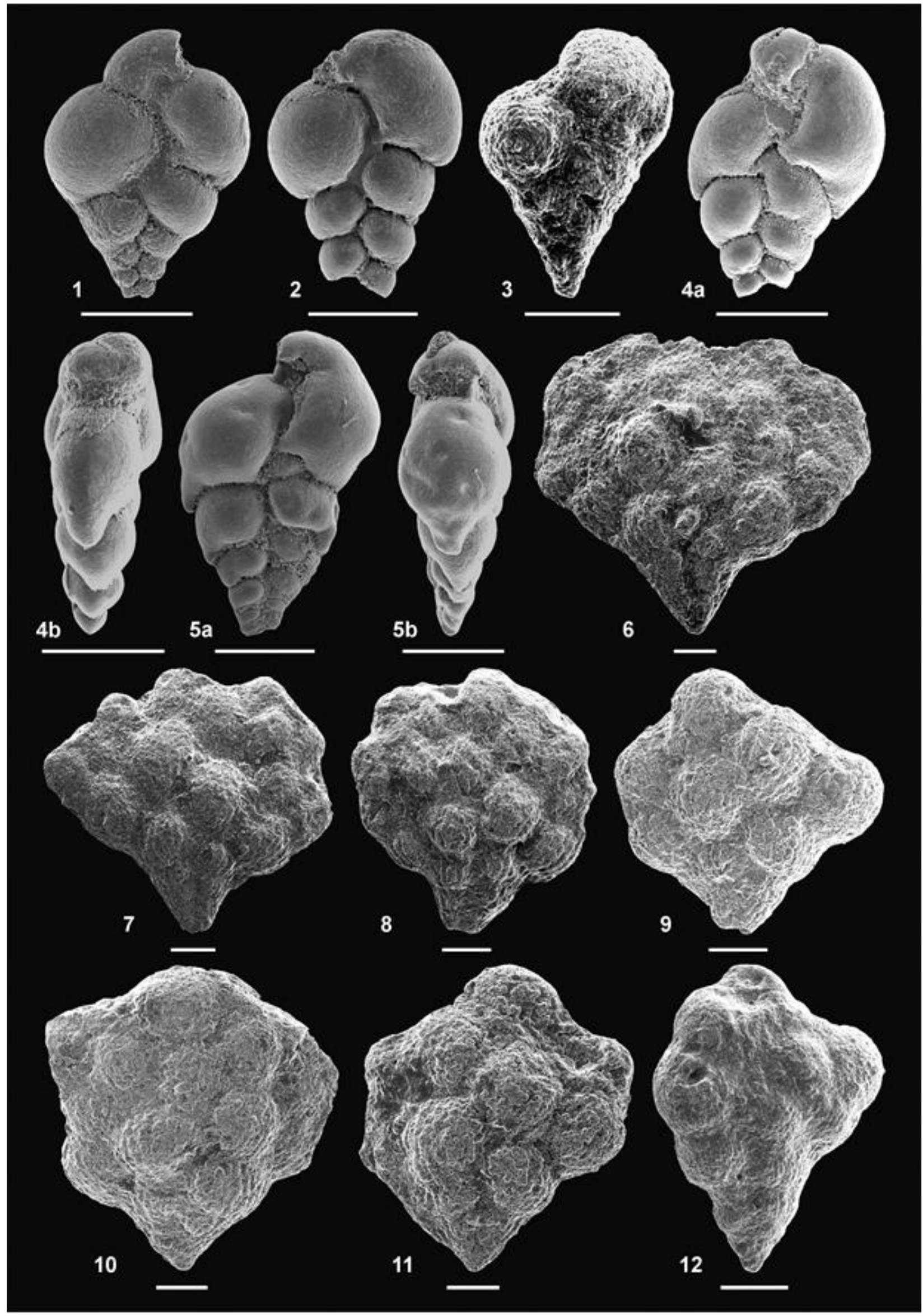




\section{PLATE 4}

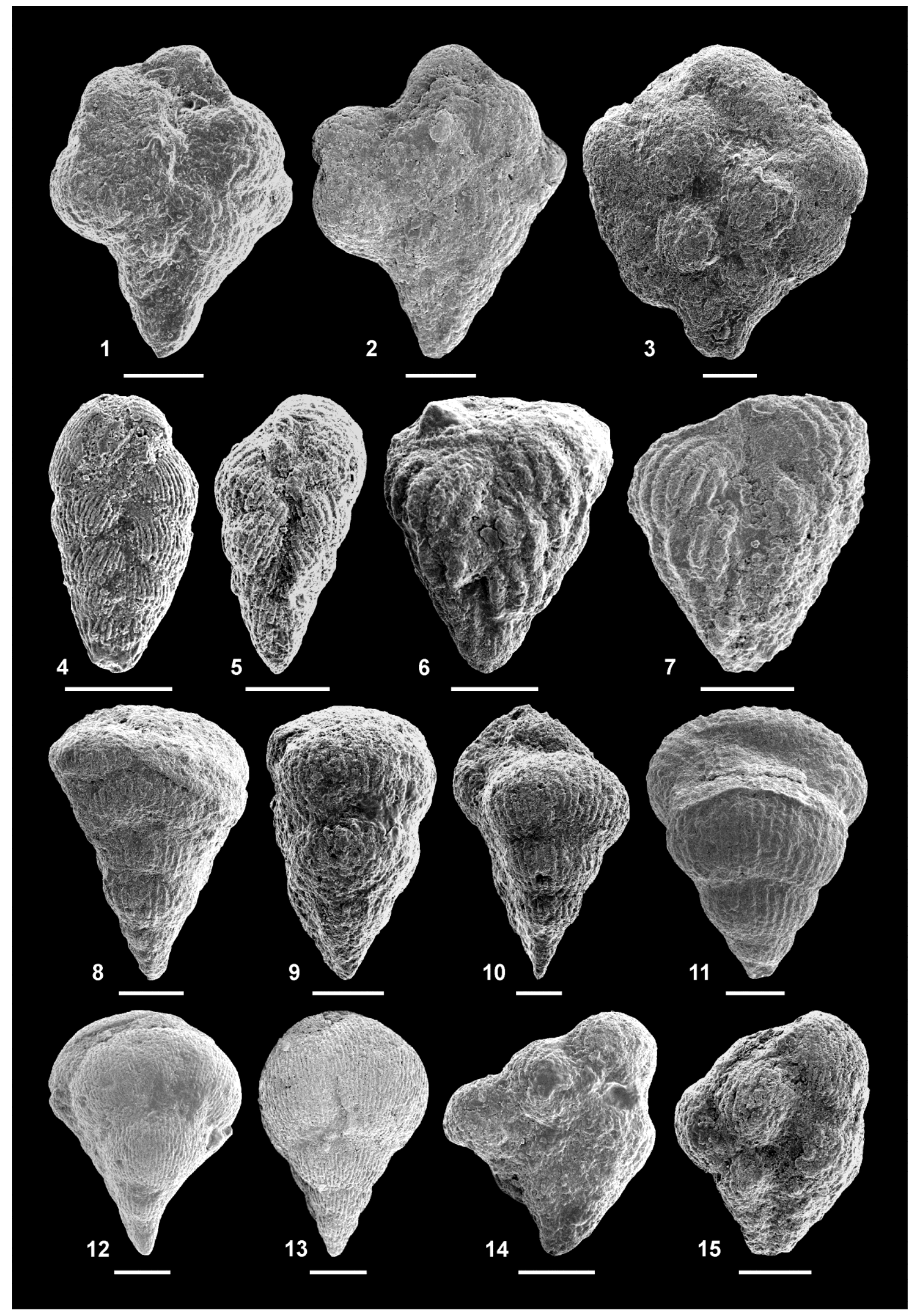


63 Biostratigraphy and Systematic Palaeontology of Late Cretaceous Heterohelicidae.....

\section{PLATE 5}
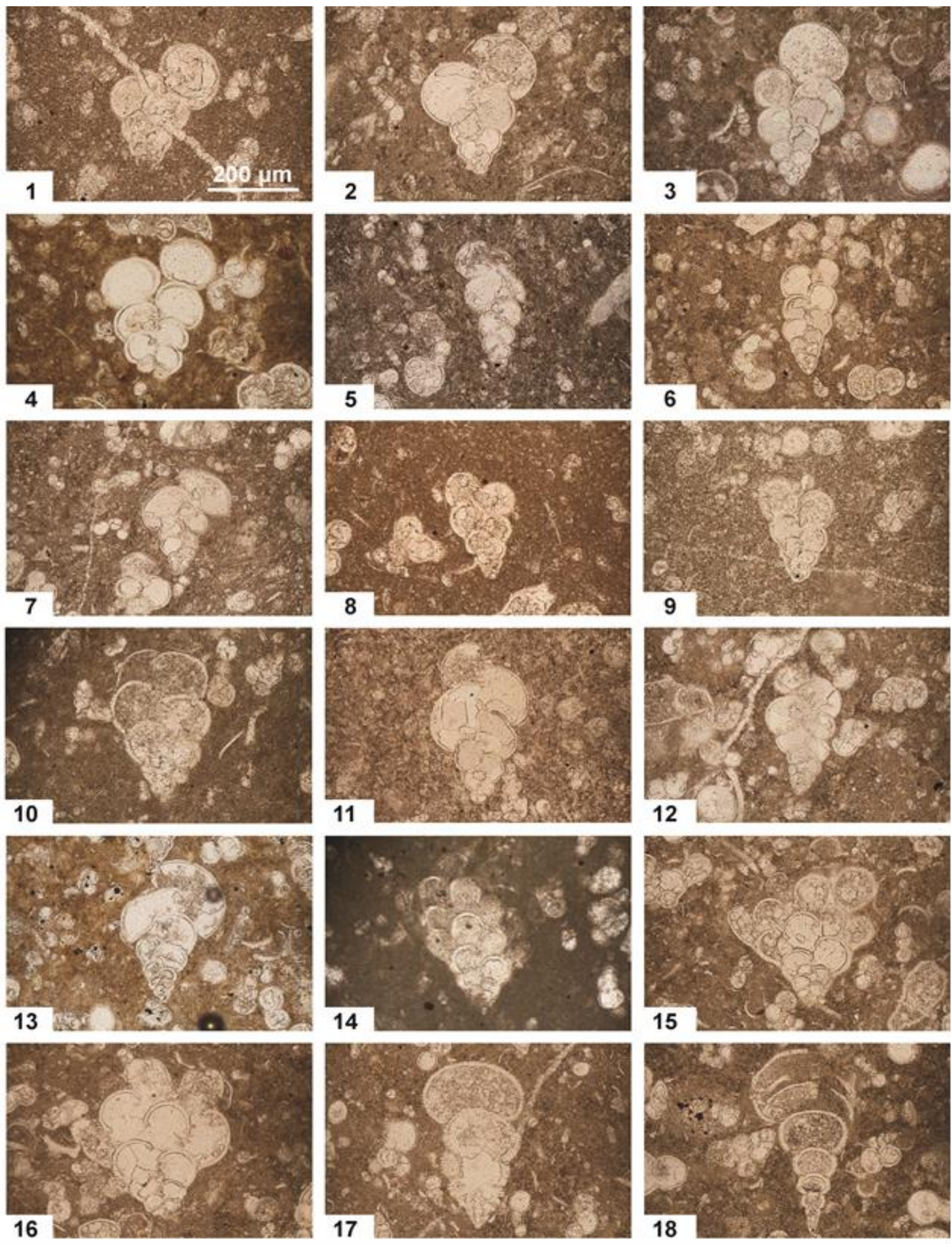